\title{
An Economic Analysis of the Choice Between Enterprise and Personal Liability for Accidents
}

\author{
Lewis A. Kornhauser $†$
}

Consider an individual acting on behalf of an enterprise such as a private business or a public agency. During the course of his duties, the individual may injure a third party who bears no contractual relation to the enterprise. ${ }^{1}$ Tort law inust then allocate the accident cost ainong three parties: the enterprise, actor and victim. ${ }^{2}$ In this Article, I shall assume that while the law has decided to shift the costs from the victim, it must choose between assigning the costs to the enterprise or to the mdividual.

This Article examines a single, important factor relevant to the choice between the legal regimes: the degree of care exercised by the enterprise and agent. ${ }^{3}$ Under one regime, called "agent liability," the individual who acts is liable but the enterprise is not. Under the other regime, called "enterprise hability," the enterprise is liable while the agent is not.

After identifying those conditions under which agent and enterprise liability produce the same levels of care and those under which they produce different care levels, ${ }^{4} \mathrm{I}$ then argue that the model

$\dagger$ Professor of Law, New York University. A.B., M.A. 1972, Brown University; J.D. 1976, Boalt Hall School of Law, University of California, Berkeley; Ph.D. 1980, University of California, Berkeley.

I have benefitted from the comments of participants at seminars at the California Institute of Technology, Northwestern University School of Law, Stanford Law School, and UCLA. In particular, Professors Lance Davis, A. Mitchell Polinsky, and Steven Wildman greatly clarified iny thoughts. I am responsible for all remaining errors.

This paper was written while in residence at the Center for Advanced Study in the Behavioral Sciences. I am grateful for the financial support provided by the Center, the Andrew W. Mellon Foundation, and the New York University Law School Research Program.

1. In particular, the victim is not, for the purposes of this Article, a fellow servant, a purchaser, or a supplier of the enterprise.

2. Throughout this Article the actor is referred to variously as the "agent," the "employee," and "he." The enterprise is called the "principal," "employer," or "she."

3. After the penultimate draft of this Article was submitted to this Review for consideration, Note, An Efficiency Analysis of Vicarious Liability Under the Law of Agency, 91 YALE L.J. 168 (1981) was called to my attention. For an analysis of the differences between that Note and this Article, see the Appendix, infra p. 1381.

4. It should be noted that the levels of care produced under each legal regime are not alone determmative of the optimal legal regime, because other normative factors, such as the extent to which the victim is compensated, might legitimately be considered. 
presented suggests enterprise liability produces greater care in the private sector. In the public sector, however, the crucial question is not on whom to assign liability but whether to impose liability on either the public enterprise or public servant at all.

The Article proceeds as follows. Part I explains more fully the nature and significance of the problem, and identifies the arguments which bear on it. Part II outlines the model used to analyze the problem. Part III identifies when the assignment of hability is irrelevant. Part IV examines circumstances under which the assignment of liability matters. Part V discusses and justifies some of the assumptions about the economics of the situation. It then discusses the implications of the model for the analysis of variants of the enterprise-agent problein. Part VI discusses the imphications of the economic analysis for the control of torts by public officials and enterprises. An Appendix provides a more formal treatment of some of the results discussed in Parts III and IV.

\section{I \\ The PROBLEM}

\section{A. The Principal-Agent Relationship}

Before outlining the factors concerning the standard of care, I will first provide an overview of the terminology of the principal and agent relationship. The conventional, economic usage of the term "primcipalagent relation" can only further confuse an already muddled area of legal terminology. To the economist, a principal is one with the right to control the output of some activity while the agent undertakes that activity. The principal controls the agent's behavior only indirectly through a contractual scheme; in particular, the principal is generally assumed unable to observe the action of the agent and hence cannot condition payment to the agent on his act but only upon the output.

In law, the terminology is more complex. The Restatement (Second) of Agency defines agency as a "fiduciary relation which results from the manifestation of consent by one person to another that the other shall act on his behalf and subject to his control."s The person on whose behalf actions are taken is the principal; the person acting, the agent. $^{6}$ There are different types of agency relations. The most significant is that of master-servant. Master-servant distinguishes those relations for which the principal has control or the right of control of the physical conduct of the agent from those for which the principal has no such control. Actual control or the right of control has legal consequences; a master is responsible to third parties for the physical con-

5. Restatement (SeCOND) OF AgenCy $\& 1$ (1958).

6. Id. $\S 2$. 
duct of servants but a principal is not responsible for the physical conduct of agents who are not servants. ${ }^{7}$

A typical master-servant relation is that of employer-employee. A typical principal-agent relation that is not a master-servant relation is chent-attorney. An attorney is generally an agent because she acts on behalf of her chent and owes that client duties of loyalty and obedience. But the chent generally has no control or right of control over the means by which the attorney carries out her task of representation. The attorney, therefore, is not a servant.

Some relations qualify as principal-agent relations in economics but not in law. Promisor-promisee (or purchaser-supplier) might be modelled economically as a principal-agent relation because one party must accept delivery before the quality of the delivered good is revealed. Purchaser-suppher is not legally a principal-agent relation because the supplier owes the purchaser no duty of obedience or loyalty.

A brief and somewhat crude statement of the liability of principals for the tortious conduct of their agents may be useful. In general, a master is hable for the unauthorized torts of his servant when those torts occur while the servant is acting within the scope of his employment. $^{8}$

The employer-inaster might be hable on two grounds. First, he might have acted wrongly himself. The master may have been negligent in his hiring or supervision of the servant. Alternatively, he may have provided the servant with unduly hazardous tools with which to accomphish the tasks. Second, the master may be vicariously liable; he may have done nothing negligent himself. In this second case, the agent as well as the principal is almost always subject to liability. But in practice the plaimtiff almost imvariably seeks satisfaction from the employer alone and the employer does not exercise his right to imdemnification. ${ }^{9}$

\section{B. Overview of the Analysis}

The analysis of the principal-agent relationship undertaken in this Article rests im part on a standard, if not classic, argument of law and economics. In The Problem of Social Cost, ${ }^{10}$ Ronald Coase argued that, in a world without transaction costs, the assignment of liability will not affect the efficiency of the outcomes. In the context of thirdparty torts by enterprises, that argument implies that agent and enter-

7. Id. $\$ 2$ comment $\mathrm{b}$.

8. The principal of course is responsible for all authorized torts of the servant. Id. § 219 .

9. Note that an agent might be immune from liability but not the principal. See 2 F. HARPER \& F. JAMES, THE LAW OF TORTS § 26.1, at 1363 (1956).

10. Coase, The Problem of Social Cost, 3 J.L. \& Econ. 1 (1960). 
prise liability produce equally efficient outcomes and therefore the same levels of care. Furtler, there is some reason to believe that transaction costs are small im the enterprise case since principal and agent have an ongoing contractual relation between them.

Three related reasons justify the focus on this narrow and seemingly simple question of the relative levels of care mduced by the two legal regimes. First, while private enterprise has been subject to a regime of enterprise liability for several decades, the choice of legal regime to govern public enterprise has been and is likely to reinain a topic of current judicial developinent. Of particular importance is the controversy over the extent of immunity that should be granted government officials. ${ }^{11}$

Second, these legal developments lave mspired a debate in the law reviews over the relative merits of various patterns of official and governmental liability. ${ }^{12}$ The current debate raises in a different context and with greater sophistication the corresponding issues concerning the liability of private enterprises and their servants that were contested at the turn of this century. ${ }^{13}$ The substantive positions of these debates turn on the relative number and cost of accidents that occur under enterprise liability as opposed to the number and cost that occur under agent hability.

Third, some of the arguments raised in the legal debate suggest differing content to the much discussed, always opaque, concept of "transaction costs." According to the Coase theorem, if agent liability leads to different levels of care than enterprise liability, "transaction costs" must be nonzero. Thus, discovery of situations in which the level of care taken under the different legal regimes is not equivalent serves

11. In the past decade the Supreme Court has dramatically recast the legal rules governing the hability of government officials (federal, state and local) and of municipalities for injuries caused by their official actions. For instance, in Bivens v. Six Unknown Named Agents of the Fed. Bureau of Narcotics, 403 U.S. 388 (1971), the Court held that unwarranted and unreasonable searches and seizures gave rise, under the fourth amendment, to a cause of action against the offending federal officials. Simce 1971, the reach of constitutional tort law has expanded to include state and local officials as well as federal and to encompass breaclies of various other clauses of the Constitution. E.g., Carlson v. Green, 446 U.S. 14 (1980) (eighth amendment). The Court's abrogation of longstanding rules of immunity from suit of municipalities and of officials, both federal and local, further extended habihity. Monell v. Dep't of Social Services, 436 U.S. 658 (1978) (municipalities); Owen v. City of Independence, 445 U.S. 622 (1980) (saine); Butz v. Economou, 438 U.S. 478 (1978) (overruling in part Bart v. Matteo, 360 U.S. 564 (1959) (dealing with federal officials)); Scheuer v. Rhodes, 416 U.S. 232 (1974); Wood v. Strickland, 420 U.S. 308 (1975).

12. See, e.g., Civil Liability of Government Officials, 42 LAW \& ConTemp. Probs. 1 (1978); Schuck, Suing Our Servants: The Court, Congress, and the Liability of Public Officials for Damages, 1980 Sup. CT. REv. 281.

13. See, e.g., Wigmore, Responsibility for Tortious Acts: Its History (pts. 1 \& 3), 7 HaRv. L. Rev. 42, 383 (1894); Holnes, Agency, 4 HARv. L. Rev. 345 (1891), Snith, Frolic and Detour (pt. 1), 23 Colum. L. Rev. 716 (1923); Laski, The Bases of Vicarious Liability, 26 Yale L.J. 105 (1916); Douglas, Vicarious Liability and the Administration of Risk, 38 YALE L.J. 584 (1928). 
to identify aspects of transactions that might be worrisome in other legal situations as well.

\section{Identification of Potential Costs and Arguments}

This Article examines several potential "costs" that might lead to different levels of care under the two different legal regimes. The essential assumption of the model is that one such cost, which is always present, is the enterprise's inability to write and enforce einployment contracts that condition the wage of the einployee on a specific level of care. Employment contracts can, however, be conditioned on observable events that are proxies for the level of care taken. These proxies may be more or less "noisy"- that is, they are less than perfectly correlated with the agent's actual level of care. The assumption that employers cannot condition on a specific level of care is quite reasonable given that principals do not observe every act of their subordinates. Similarly, while courts resolve controversies, they do not, with certamty, ascertaim the degree of care exercised by the agent. In fact, the model will restrict enterprises to a very narrow set of contracts defined by the proxy which may be used in employment contracts.

The other potential costs examined derive from arguments offered elsewhere in the legal hiterature. First, the agent may not have sufficient assets to cover the judgment, in which case his hiability would be limited. If the agent has insufficient assets to cover the dainage he causes, the assignment of liability to him arguably will not completely internalize the costs of his decisionmaking. Some of the loss will still fall on innocent third parties, and the agent will take too little care ineasured from a social perspective that seeks to minimize the sum of accident costs and accident prevention costs. ${ }^{14}$ To complete the argument, one must be able to conclude that assigning liability to the financially solvent enterprise will increase the care taken by the agent.

Second, employers may not screen their employees on the basis of carefulness. Unless the enterprise is liable it will be indifferent to the carefulness with which its agents undertake their tasks. It may therefore hire too many careless employees and again too many accidents may result. This argument assuines, of course, that the injury-causing activity is not related to the efficiency with which the agent achieves the goal of the enterprise. If inore careless employees also produce more profit for the enterprise, this second justification would suggest that enterprises would hire far too many careless people. Conversely, if lack of care hindered productivity, enterprises would have soine, but perhaps inadequate, incentive to screen applicants on the basis of care.

14. Mashaw, Civil Liability of Government Officers: Property Rights and Official Accountability, 42 LAW \& CONTEMP. Probs. 8 (1978). 
Third, failure to assign liability to the enterprise arguably leads to the provision of a work environment that is too dangerous to third parties. The danger may arise either from the inadequate supervision of workers or from the arrangement of the production process in a way that enhances profits at the cost of injuries to a third party and borne by the employee. Again this argument suggests that enterprise liability would induce higher care levels than agent. liability. ${ }^{15}$

Fourth, assignment of hability to the agent may be inadequate because most injuries result from a complicatcd combination of acts by various agents. Courts are unable to disentangle the event and hence many agents escape liability because the plamtiff cannot prove a particular agent was at fault. Thus, for reasons similar to those considered under the first rationale, too many accidents occur. Assignment of liability to the enterprise not only insures compensation of the victim but places responsibility on a party either better able than the court to identify the responsible individuals or with a wider range of sanctions available.

Fifth, there is a conflict of imterest between agent and principal in which the agent prefers, if all else is equal, to take less care, while the principal cares only about her profit. This rationale assumes that the agent's exercise of care decreases productivity so that if lie takes inore care, enterprise profits fall. However, under a rule of law that assigns liability to the agent, the agent's interests conflict with those of the enterprise. Thus, in order to avoid liability, he might take more care than he otherwise would under enterprise liability. Consequently, from an economic standpoint, too few accidents and too little profit (or governmental service) would be produced ${ }^{16}$ under agent liability.

Sixth, for unspecified reasons, the entity cannot communicate incentives to the agent. Enterprise liability would then lead to more acci-

\footnotetext{
15. Bentham offered versions of both the second and third arguments:

The obligation imposed upon the master acts as a punishment and diminishes the chances of similar misfortunes. He is interested in knowing the character, and watching over the conduct of those for whom he is answerable. The law makes him an inspector of police, a domestic magistrate, by rendering him liable for their imprudence.
}

Principles of Penal Law, in 1 J. BenthaM, Collected Works 383, quoted in Laski, supra note 13, at 113-14.

16. Assistant Attorney General (then Professor) Baxter recently made this argument in a symposium on liability of government officials:

Pecuniary responsibility on the part of employees leads to internal inefficiency not because employee behavior is unresponsive to the prospect of such liability but because it is too responsive. Liability induces the employee to adopt behavior that is suboptimal from the standpoint of the employer. Pecuniary responsibility forces employees to choose between protecting their own purses and executing the programs of their employers with zeal and imagination. We should not be surprised to find that employees who face such a choice strike a different balance than would those who had to bear both the costs of harm to outsiders and the costs of ineffective inplennentation.

Baxter, Enterprise Liability, Public and Private, 42 LAW \& CONTEMP. ProBs. 45,49 (1978). 
dents than agent liability because the courts may provide incentives that the enterprise cannot. ${ }^{17}$

The Article therefore examines seven factors that might potentially lead to different care levels prevailing under the two legal regimes: (1) limitations on contractual form that derive from imprecise monitoring of agent care; (2) conflicts of interest between principal and agent; (3) costs of screening employees on the basis of carefulness; (4) partial control by the enterprise of the probability of an accident; (5) limited liability of the agent; (6) additional non-labor market impediments to the contractual form; and (7) differences in court and enterprise ability to hold agents responsible. In every case examined, the limitations on contractual forms and the conflict of interest between agent and principal will exist. The precise meaning of each of these costs will be specified later in the Article.

\section{Summary of Conclusions}

The results of the analysis may be simply stated. Agent liability and enterprise hability induce the same level of care in the basic case in which the enterprise cannot condition wages on the exact level of care taken and in which the agent's imterests diverge from the interests of the primcipal. In addition, the two legal regimes lead to the same levels of care when the problems of supervision and screening are added to the basic conflict of mterest and to the limitation on contractual forin. On the other hand, the legal regimes lead to different levels of care when the two basic costs are complicated by limited liability of the agent, a difference between court and enterprise ability to identify responsible agents, or some additional restriction in the enterprise's ability to condition its einployment contract.

Under limited liability, the level of care under agent liability may be greater than, equal to, or less than the level of care induced by enterprise hability. Casual empiricism would suggest that when there is limited liability, less care is usually taken under agent liability. Generally, enterprises are inore able than courts to identify responsible actors; consequently, this fact suggests that more care results from a system of enterprise hability. Similarly, differentials between court and enterprise ability to monitor care can lead to different levels of accidents. Which regime of liability induces greater care levels depends on wlich institution, court or enterprise, nomitors better. Conversely, if for reasons unrelated to the labor market, the principal is restricted in her ability to condition wages even on noisy indicators of care, then agent liability leads to more care than enterprise liability. Tlis latter result lias special significance for the public employee case in which civil

17. Mashaw, supra note 14, at 22-23. 
service regulations may restrict the government's abihity to condition wages, broadly defined, on performance.

II

THE MODEL

The model derives from two sets of assumptions: those about the behavior of the parties and which describe the nonlegal environment in which the parties act, and those describing the legal environment. There are three parties involved in the problem-the victim, the agent, and the enterprise. In Section A, I consider in turn the behavioral assumptions and nonlegal environment of each, and in Section B the legal environment.

\section{A. Assumptions About the Nonlegal Environment}

\section{Behavior of the Victim}

In this model, the victim plays a passive role. The victim does not exercise care and hence cannot affect the likelihood that an accident will occur or the amount of damages suffered. Further, the victim has no contractual relation with the enterprise or the agent. In particular, the victim is not a consumer of a product that causes the accident. In product hability cases, for instance, the product inarket inight provide the enterprise with additional incentives to control the behavior of the agent. Thus, as will be noted below, the presence of a product inarket as well as a labor market may affect the impact that limited liability has on the comparison between legal regines. Sinilarly, the victim is not a fellow employee in which circumstance the labor contract with the victim may provide additional incentives to the enterprise. Despite the exclusion of these two major types of situations, accidents that fall well within the purview of the model frequently arise and are easy to outline. Auto accidents caused by einployees and nost torts committed by public officials are common examples.

\section{Behavior of the Agent}

In the basic model the agent unilaterally determines the frequency of accidents through his choice of care level. I assume that the agent, seeking to maximize his utility, considers three factors: his incoine, the care level chosen, and the degree of risk to which he is exposed. Agents prefer more money to less, taking less care to taking more care, and facing smaller risks to facing larger ones. ${ }^{18} \mathrm{~A}$ labor inarket determines

18. If the agent is indifferent to risk, the optimal action on the part of the principal would be to make the agent liable for any damage caused. The principal should always seek indemnification against the agent. 
the agent's wage. This means that employers must offer agents some combination of wages and freedoin from care and risk that guarantees agents an expected utility level at least as high as they could get in alternative employment.

Sometimes it is converient to think of the alternative employment as riskless and the utility that must be guaranteed that which derives from receiving the wage offer for this riskless activity. One can then think of the employer as required to meet this market wage, which I will refer to as the "reservation wage."

The degree of competitiveness of the labor market does not affect the analysis unless the extent of market power is affected by the legal rule. One would not expect that the ability of the labor market to determine the wage rate depends on whether agent liability or enterprise liability prevails because it is unlikely that the agent's power in the labor market varies with the choice of legal regime.

The agent chooses his level of care in response to the particular wage contract offered. As noted at the outset, and as will be elaborated below, this contract may condition the agent's wage on some proxy ${ }^{19}$ for the level of care he chooses. Unless a proxy gives some information about the level of care actually cloosen, the employer will not use it in a contract; equivalently, only those proxies whose value depends on the actual care level chosen will be used in contracts. Therefore, if wages are conditioned on a proxy, the agent can calculate his expected wage through his choice of care level. I assume the agent chooses his care level to maximize his utility given the wage contract he faces.

Under agent liability the employee receives a nommal wage, perhaps dependent on some proxy for his care level. If an accident occurs the agent must also pay damages of amount $D$. Damages per accident are assumed fixed; this only simplifies exposition. His net imcome is his wage less the damage award. The agent affects the likelihood lie will have to pay damages through his choice of care level; I assume the agent knows the relation between his care level and the frequency of accidents. He also knows which liability rule prevails.

In two of the cases examined below, concerning "screening" and the "work environinent," the frequency of accidents depends not only on the agent's choice of care but also upon some action of the enterprise. In the first case, it depends on how carefully the enterprise screens for more careful agents. Obviously, the choice problem of the agent is not complicated by this factor. In the second case, the enterprise provides a work environınent which determines the effect that the agent's choice of care will have on the frequency of accidents. The

19. Examples of such proxies include the number of accidents an agent causes or, in an automobile driver case, the number of traffic citations he receives. 
enterprise chooses the work environment before the actor chooses his care level. In this circumstance, I assume the agent knows both the nature of the work environment chosen and the relation between his choice of care and the frequency of accidents given the known choice of work environment. Both these assumptions are a bit unreasonable. For instance, one way the enterprise may affect the frequency of accidents is through its choice of inaterials with which the agent works. If the agent drives a car supplied by the enterprise, he may not know how safe that particular car is, though, if he did know, he would probably know how his care choice affected the overall frequency of accidents. I adopt these nonetheless because first, understanding the posited situation is a likely precondition to understanding more realistic situations; and second, agents who act repeatedly in the same job might acquire the assumed knowledge through experience.

\section{Behavior of the Enterprise}

In the basic model, the enterprise selects the wage contract offered to employees. The principal makes this clooice in a inanner that maximizes her expected utility. The principal's utility depends on the agent's output, the costs of producing that output, and the degree of risk to which the principal is subjected.

The costs of producing output only depend on the wages of the agent and any hability to which the principal might be exposed. This model thus ignores the principal's evaluation of the agent's productivity. This means that I assume the agent's choice of care does not affect the agent's level of output. This assumption does not alter the conclusions of the inodel. Including an affect on output only coinplicates the formal analysis without changing the results. The assumption does mean that the only conflict of interest explicitly inodeled derives froin the fact that the agent's utility depends directly on his choice of care while the principal's depends only indirectly upon the agent's choice of care. If the primcipal were exposed to liability and wages were fixed, she would always prefer that the agent take more care no matter how expensive or distasteful it were to the agent because more care reduces the likelihood and therefore the cost of accidents. On the other hand, the agent under that system would always prefer to take less rather than inore care.

The principal's choice of wage contract is constrained by three factors. First, she inust offer a wage contract at least as attractive to the agent as the agent's reservation wage. Second, since the principal cannot momitor perfectly the agent's conduct she inust, in selecting a wage contract, take into account the fact that the agent will choose his level of care to inaximize his utility given the wage contract. I assume the 
principal knows the utility function and reservation wage of the agent. Thus, for any wage contract she can predict the level of care that will be chosen. Since I also assume the principal knows the relation between agent care and accident frequency, she knows the liability costs that will be associated with any wage contract. Third, I assume that the firm must choose a wage contract of a very specific form: the primcipal may only condition the wage on whether an accident occurred or not. ${ }^{20}$ This constraimt allows the primcipal to offer a uniform wage or to imclude an insurance clause for the agent under agent liability or an indemnity clause under enterprise liability. In this model, no better proxies for the agent's level of care exist; but the agent can affect his expected wage through his choice of care level because his care level determines the frequency with which accidents occur.

Allowing the principal to write more complicated contracts based on inore accurate proxies for the agent's care level would not alter the conclusions of the analysis; it would only complicate the analysis in several ways. First, the choice of proxy would affect the costs of contract enforcement. Presumably proxies that give a more refined knowledge of the level of care chosen by the agent are more expensive to enforce. Thus, the restriction on contract form suppresses a question of the choice of optimal contract form. This optimal form, however, will not depend on the rule of liability. If complicated contracts and extensive momitoring of care levels are desirable under one legal regime, the analysis below suggests that they will be desirable under the alternative regime because the labor market will transmit the relevant costs. Second, more refined proxies would force us to consider unore variables in analyzing the outcomes.

\section{B. Assumptions About the Legal Environment}

The restriction on contract forms has consequences for the assumptions inade about the legal regime. It seems plausible that the

20. The damage, of course, must be objectively observable. That is, the plaintiff's claim of damage, if it is an imdicator at all, is a very crude and unsatisfactory one. Proof of some torts does involve more subjective indicia of damage than objective ones. It is, for exmple, more difficult to verify the presence of emotional distress than of broken arms. Arguably, some constitutional torts cause damage that is difficult objectively to see. Many constitutional torts, however, are accompanied by an uutoward event that may signal possible care. Someone is demied the opportumity to speak, is searched or seized, or confesses. Of course the principal may be able to use compensation schemes that a court cannot duplicate. Some of these are not permitted in the model as formulated. For instance, the principal might condition the agent's payment not on the event of an accident but on his accident history. Accident history is a better indicator of the agent's care level than the fact of a particular accident so that this more sophisticated compensation schene will improve the welfare of both principal and agent. See, e.g., Radner, Monitoring Cooperative Agreements in a Repeated Principal-Agent Relationship, 49 ECONOMETRICA 1127 (1981); Rubinstein, Offenses That May Have Been Committed By Accident-An Optimal Policy of Retribution, in APPLIED GAME THEORY (1979). This scheme is available under both assignments of liability. 
enterprise can better observe the care level of her agents than the courts. One would therefore expect that court rules determming the hability of the principal-agent nexus for accidents would not use a more refined proxy for care than the one employed by the enterprise. If this is the case, then the restriction to contracts conditioned only on the event of accident compels the assumption of a strict liability rule governing accidents. Indeed, that assumption is made.

I beheve the strict hability assumption is harnnless. If the rule of liability were neghience, the enterprise could condition its wage schedule on findings of neghgence and rates of settlement of accident claims. In this way, its proxy for agent care would be at least as good as the court's witliout effectively increasing the costs of contract enforcement. Further, court-determined findings of neghigence are not certain and precise findings of the actual level of care chosen. They are proxies for that level of care, albeit more refined proxies than the presence or absence of an accident. Thus, shifting to a sclieme of negligence liability only comphicates the analysis; the conclusions drawn froin examining the strict hability model transfer directly to the more realistic case.

Several other assumptions about the legal regime are made. First, the decision to impose hability on the principal-agent nexus has been made. In reahty, however, not all mjuries caused by mcorrect or even wrongful decisions are remediable by law. For example, Masliaw has argued that problems of governmental liability are particularly plagued by inconsistencies in the decision to impose liability. ${ }^{21}$ As developed below, the asymmetric imposition of liability for wrongs caused by $\mathrm{m}$ action as opposed to those wrongs caused by action may, under suitable assumptions about the preferences of the principal, lead to undesirable beliavior on the part of principal and agent under both regimes.

Second, no legal problems concerning the question of when an employee is acting in the scope of his employinent exist. Of course, much hitigation centers precisely on this issue and the uncertainty produced by the law governing this question nay affect the behavior of both principal and agent. Nonetheless, the analysis suggests that in many cases the assignment of hability does not matter for accidents in which the agent's behavior is unrelated to output. A clear liability rule then would not yield different standards of care despite the uncertamty in the law governing scope of employinent. The only effect then would be that victims might be better compensated if the scope of employment were interpreted broadly.

Third, the model assumes that there is only one defendant. ${ }^{22}$ Generally, altlough not always, the cause of action against the agent sur-

21. Mashaw, supra note 14 , at 22-24.

22. For an account of the current law, see Schuck, supra note 12, at 316-20. 
vives which means that the victim may sue both principal and agent. ${ }^{23}$ The assumption of only one defendant, however, simplifies significantly the exposition without making the analysis unreasonable. In most instances where the cause lies against both agent and principal, the victim sues only the principal. If botl principal and agent may be sued, one must consider plaintiffs' choice of defendants and defendants' ability to join third parties as co-defendants. One would expect that the employment contract would handle these difficulties as well as the assignment problem in its pure form. After all, the results of the analysis are little affected by the assumption.

Fourth, I assume that insurance and indemnification clauses are legally permitted im wage contracts. If these provisions were strictly barred, the two liability regimes would lead to different care levels in those circuunstances where under the current analysis they lead to identical outcomes. Alternatively, insurance and indemnification results would be reproduced through complicated contractual devices that were more costly to implement than straightforward clauses.

The essential elements of the model may be briefly restated. An agent acting on behalf of an employer chooses a level of care that determines the probability of an accident. Both agent and primcipal know the relationship between the level of care chosen and the frequency of accidents but only the agent knows the precise level of care actually chosen. The principal seeks to minimize his wage bill plus, under enterprise hability, her liability. The legal system assigns liability to the principal-agent nexus on a strict liability basis. It must choose between two assignments of liability: agent liability under which the agent is liable but not the principal and enterprise liability under which the principal is liable but not the agent. The following two Parts analyze the choice of the levels of care under each legal regime and in the presence of several different costs.

\section{III \\ The Equivalence of Agency AND ENTERPRISE LIABILITY}

This Part analyzes three cases in which a clioice between enterprise and agent liability does not affect the level of care selected by the agent. The first case treated, called the "benchmark," is of special significance because every subsequent case incorporates its basic features-a restriction on the contract forms the einployer may offer and a conflict of interest between principal and agent. The other two cases

23. In the federal system, liability of the United States precludes an action against the agent. 28 U.S.C. $\$ 2676$ (1976). Liability against the United States, however, is quite restricted. Id. $\S 1346$ (Supp. IV 1980). 
examined add to this benchmark case the factors of screening for inore careful agents and the possibility that the work environment provided by the principal can alter the likelihood of accidents. In all of these cases, the assumptions set forth in Part II still apply.

\section{A. The Benchmark Case}

To begim, consider a benchmark case. The elements of this case will be incorporated in every subsequent analysis. This benchmark focuses on two potential sources of divergence in the care level under the two legal regimes. First, the employer can only condition wages on the presence or absence of an accident. Second, the basic conflict between principal and agent is introduced: the agent, unlike the principal, would prefer that he take less rather than inore care. Thus, in the benchmark case, all other considerations are ignored; in particular, I assume a world in which: (1) the principal has no control over whoin she may hire; (2) she can provide a single work environment that permits a fixed range of carelessness on the part of the agent; (3) the responsible or irresponsible agent is readily identifiable; and (4) both the agent and the principal can meet any liability that the courts might mipose on them. In this world, the assignment of hability will not change the level of care exercised by the agent.

Two different arguments establish the equivalence of the choice of care levels under each legal regime. The first rehes only on the logic of maximization and the fact that, under each pattern of liability, the legal system allows the employment contract to include indemnification or insurance claims. It follows that the compensation scheines available to the principal are identical under the two patterns of liability. Under agent hability, the principal may put herself in the enterprise liability world by insuring the agent. Under enterprise liability, the principal may recreate the world of agent liability by charging the agent the amount of damage in the event of an accident. Thus, any care level and utility attainable under one systein of hability is theoretically attamable under the other; the levels of care optimal from the principal's perspective must therefore also be equivalent.

The second argument focuses on the econoumics of the situation. Consider the optimal wage scheine where the enterprise is liable and where the caretaking activity does not affect the output produced. The principal clearly sees the costs of her agent's carelessness because she must pay the damage awards. But the principal also sees the benefits of her agent's carelessness because it is costly for the agent to take care.

The agent is "freer" from care the less his wage depends on the presence or absence of an accident. If, for example, the agent receives the same wage in the event of an accident as in the event of no accident, 
he will take no care at all because care does not affect his income or his risk. As the differential between the wage in the event of no accident and the wage in the event of an accident increases, the agent will take more care. While taking care is costly for the agent, it does have two benefits: it mcreases the average wage he will receive and it decreases the risk to which he is exposed.

Now consider any wage contract. The amount of care the agent takes depends on the difference between the wage in the event of no accident and the wage in the event of an accident, and the extent to which the agent dislikes risk. As the difference increases, the expected damage awards the principal must pay decline while the average wage the principal must pay rises. The principal will choose a contract such that, if she altered the wage differential an infinitesimal amount, the decline in expected damage payments would equal the increase in expected wage payments. In this maimer, the principal will minimize the total amount spent on wages and damages. ${ }^{24}$

According to this second argument, enterprise and agent liability produce the same levels of care because the principal's calculation is no different under a system of agent liability. As the damage payments made by the agent increase, the expected wage net of damage payments to the agent must rise lest the principal be unable to attract employees. The principal could simply insure the agent against liability and induce the agent to take care by conditioning the compensation scheme on the amount of insurance awards made. Thus the principal, under agent hability, will choose a wage contract such that the infinitesimal decline in expected insurance claims equals the infinitesimal increase in expected wage increase payments. Therefore, the principal will offer identical contracts under agent and enterprise liability except that the principal will insure the agent under agent liability. Since the agent dislikes risk, the difference between his wage wlien no accident occurs and his wage im the event of an accident will be less than the amount of damage. The more risk averse the agent, the more of the risk the principal will bear. On the other hand, the principal will not completely protect the agent from the risk of loss because then he will take no care. The best arrangement imsures the agent against loss under the agent hability regime but then penalizes him in the event of accident by reducing his wage. Thus, the net penalty on the agent is less than the damage done.

Although the argument offered above assumed for the sake of sim-

24. Strictly speaking, the argument in the text applies only for principals who are risk neutral. A risk-averse principal will choose a wage contract in a similar manner by taking into account not only the expected wage and damage payments, but also the degree of risk to which it is exposed. 
plicity that caretaking does not affect output, the argument in no way depends upon the separation of caretaking activity and production. If the agent's choices affect not only the probability of an accident but also the amount of output produced, the principal will still see all the effects of the agent's choice. The benefits of carelessness to the principal would imclude not only lower wages but higher output (if carelessness and greater output are positively related) while the costs of carelessness are higher expected damages (or expected insurance claims). Since under both enterprise and agent liability systems the principal sees these same costs and benefits, she will still choose compensation schemes that differ only in the presence of an additional insurance contract for the agent under agent liability.

Two features of the above arguinent should be emphasized. First, the costs and benefits of different liability systems to the agent are coinmunicated to the principal through the labor market. Labor unarkets, of course, are imperfect. But they are imperfect under both agency and enterprise liability. For the imperfection to alter behavior, it unust have asymmetric effects under the two hability systems. Such asymmetries are hard to imagme. For instance, the presence of monopoly power on either side of the market should have identical impact on the liability systems. The party with monopoly power will extract monopoly rent under both systems, unless the power derives from the presence or absence of liability.

Second, the ideal compensation scheme, both in the benchmark case and the cases to follow, conditions payment on the adverse outcome (an insurance claim or a damage award). While in the real world agents may nominally receive wages or salaries independent of their accident-producing activity, incentives may be built into compensation schemes in complex ways. Prospects for promotion, increased salary or contmued employment may depend on the adverse outcome. The fact that wages do not vary directly with the adverse outcoine therefore does not directly refute the conclusion above.

\section{B. Screening for More Careful Agents}

An alternative to controlling the behavior of the agent contractually is to screen the applicants for jobs on the basis of carefulness. This Section will demonstrate that this ability to screen does not affect the levels of care under the liability regimes.

Suppose there are two types of agents: careful and careless. The first are more careful than the second in the sense that for any given level of care the cost of increasing the care level is less for careful agents than for careless agents. Again the employer can condition his 
contracts only on the presence or absence of an accident. Further, the same contract must be offered to all agents.

The screening of job applicants is costly. The more money the principal expends on screening the more likely it is that she can distinguish careful from careless applicants who arrive randomly at her door.

More screening reduces the expected accident costs. The principal will choose to screen as long as the sum of the increased screening costs plus the increase in the wage bill is less than the reduction in the expected accident costs. The addition of the screening option does not alter the conclusions of the benchmark case because the levels of care exercised under each legal regime are equivalent. If it is profitable to screen im the enterprise liability case it will also be profitable in the agency hability case because the principal inust also insure the agent against liability (or she will not attract workers). Thus, liability costs appear as insurance claims. Screening and care results will be identical under both patterns of liability.

\section{The Structure of the Work Environment}

Since the inanner in which the employer structures the work of the agent inay affect the likelihood of injury to third parties, one miglit contend that the work environinent will change for the better if enterprise as opposed to agent liability is imposed. Arguinents similar to those outlined above again suggest that the assigninent of liability will not alter the behavior of either principal or agent.

In the situation considered in this Section, the probability of injury depends not only on some level of care chosen by the agent but also upon soine level of care chosen by the principal. The agent will respond to inaximize his own advantage given the principal's choice of a work environment. Consequently, the labor market will again transmit the appropriate costs and benefits under both assigninents of liability. ${ }^{25}$

25. A more formal proof of this would be as follows. Let $\mathbf{y}^{\mathbf{P}}$ represent the principal's optimal care level under enterprise liability and $y^{A}$ lier optimal care level under agent liability. $y^{P}$ must equal $y^{A}$ or the (assumed) optimality of the choices would be contradicted. Suppose, for example, that $y^{P}$ is greater than $y^{A}$. For $y^{P}$ to be optimal under enterprise liability implies that the (utility) cost of increasing care (under enterprise liability) from $y^{A}$ to $y^{P}$ was more than compensated by the decrease in the (utility) of the sum of expected wages and expected accident costs. These decreases would result from the changes in the wage structure (and resulting change in agent care levels) that would accompany a move froun $y^{A}$ to $y^{P}$. But the principal "sees" the saune costs under agent hability as under enterprise hability and the same set of contractual forms are available to her. Therefore the move from $y^{A}$ to $y^{P}$ would be desirable under agent liability as well. Consequently $y^{P}$ must not be greater than $y^{A}$. A similar argument establishes $y^{A}$ must not be greater than $y^{P}$. Consequently, enterprise liability leads to the same choice of care level by the agent and by the primcipal as agent liability. 


\section{IV}

\section{WhEN THE ASSIGNMENT OF LiABILITY MATTERS}

In this Part, I analyze five additional variants of the benchmark case. ${ }^{26}$ First, I consider situations in which the agent has insufficient assets to pay dainages. In this case, the relation between care levels selected under enterprise hability to those chosen under agent hability is ambiguous. Depending on the parameters of the model, including the amount of the dainage, the extent of the agent's assets, his degree of risk aversion, and the "technological" relation between care and the likelihood of accidents, the agent's care under enterprise liability may be less than, greater than, or equal to that under agent habihity. Next, I consider situations in which the employer's ability to write contracts is more restricted than in the benchmark case. Here, agent liability lcads to at least as much care as enterprise liability. Third, I consider heuristically the effect of differential costs of enforcing liability judgments. Fourth, I consider the effect of nonpecuniary incentives on the two legal regimes. Fifth, I examine accidents that result from the joint behavior of multiple agents. In this case enterprise liability leads to at least as much care as agent liability. Finally, I analyze the situation in which courts assume care levels with different accuracy than principals. If courts are less accurate, this case reduces to case four.

\section{A. The Ambiguous Case of Limited Liability of the Agent}

Because an agent may not have sufficient assets to ineet his hability, liability arguably should be imposed on enterprises that can satisfy the entire judgment. This Section shows that the existence of himited hability of the agent does not logically exclude the possibility that the agent may exercise less, equal or more care under agent liability than under enterprise hability. The agent, however, will most likely exercise greater care under enterprise liability where the enterprise "sees" the total cost of the agent's conduct.

Advocates of enterprise liability inay argue that an agent's potential insolvency makes agency liability undesirable. Two reasons are offered. First, and perhaps most important, if the agent is hable and insolvent, the victim remains uncompensatcd. Since tort law seeks, at least in part, to compensate wrongfully injured individuals, the agent's inability to pay weighs heavily against an assignment of liability to him. In addition, a judgment proof defendant arguably has little incentive to take care. Imposing liability on the agent does not internalize completely the cost of his action because he cannot satisfy the damage

26. As in Part III, all of the behavioral and non-legal assumptions set forth in Part II are still applicable. 
award. Conversely, assigning liability to the enterprise will, it is argued, give the principal the appropriate incentives to take care.

Consider the situation in which the colnpensation scheine provides the principal's sole device for controlling the agent. The situation in which the principal may screen potential agents on the basis of carefulness and in whicl the principal may arrange the work task in more or less dangerous ways will be treated below.

The arguments in Part III relied on the fact that under eitlier assignment of liability, both sides "saw" the full cost of failure to take care. The liability system imposed the cost on one party while the labor market communicated that cost to the other party. If the agent's assets (which I denote by B), however, are less than the amount of potential damage (which I denote by $D$ ), the two schelnes of assigning hability are not symmetric in revealing the costs of failure to take care. Under enterprise liability, the principal sees the full cost of an accident and she will have an imcentive to reveal this cost to the agent. Under agent liability, however, the agent may see less than the full cost of the accident. The victim will bear the rest of the dainage, equal to D - B, which I will refer to as the "unfunded liability." The inarginal benefits from increasing care then would only be $\mathrm{p}^{\prime}(\mathrm{x}) \mathrm{B}$ instead of $\mathrm{p}^{\prime}(\mathrm{x}) \mathrm{D}$, where $\mathrm{p}^{\prime}(\mathrm{x})$ is the marginal increase in the probability of no accident given care level $x$. The agent would then take less care than he would if his assets exceeded the damages.

Determining whether the agent takes more or less care under agent liability than enterprise liability, however, proves difficult. There are three possibilities. If the agent's assets before the wage contract are less than the damages, under agent liability, he may either take less care, equal care, or more care than under enterprise liability. None of these possibilities can be excluded on logic alone.

One would expect that the agent will take less care under agent hability than under enterprise liability in this limited liability case. The agent will clearly take less care when the agent is close to risk-neutral, has limited assets, a small reservation wage, and the dainages are greatly in excess of his assets. Under these circuunstances, the principal would, under agent liability, choose to pay the agent a wage of zero in the event of an accident. This is because paying the agent a small positive wage less than the unfunded liability in the event of an accident would not imcrease the agent's level of care-it would just be used for indemnifying the victim, and reducing the unfunded liability to the victim. Only if the wage in the event of an accident exceeded the unfunded liability would the agent receive any net proceeds. Since we assume here that the unfunded liability is large, there would be no 
point, from the principal's point of view, to pay the agent any positive wage in the event of an accident.

Under enterprise liability, the same wage scheme would result in increased costs to the principal. If the wage contract included an indemnity clause under which, in the event of an accident, the agent would turn over his assets to the enterprise, the principal would be faced with an additional cost of the unfunded liability. If the wage paid in the absence of an accident were small relative to the unfunded hability, the principal could lower his costs by increasing the no-accident wage under enterprise liability. This would induce the agent to take more care, which in turn would lead to lower hability costs for the principal.

Wage costs to the principal would increase in two parts. First, there would be an extra wage cost of the probability of no-accident times the differential between the optimal wage contract under enterprise liability, and the wage contract under agent liability. This corresponds to the extra wage costs in the situations where the agent already prevents accidents. Second, there would be an extra wage cost of the marginal increase in the probability of no-accident times the new optimal wage rate. This corresponds to the increased wage paid under situations where the agent takes care under the new wage, but would not have taken care under the old wage.

Liability costs to the principal would decrease by the marginal change in the no-accident probability times the unfunded liability. This corresponds to the lower number of situations in which the principal must pay the unfunded costs of accidents. If the change in wages is sufficiently small and the unfunded liability is sufficiently large, the principal will induce the agent to take more care under enterprise liability than agent hability.

Of course, the no-accident wage under agent liability need not be small relative to the unfunded liability. In particular the agent's assets might be substantial but still less than the dainage he inight cause. If the agent were extremely averse to risk, the principal miglit liave to pay him a great deal in the event of no accident, if the agent were to bear the risk of having nothing in the event of an accident. Let us consider this case. The principal has a number of alternatives. First, it might be best, even under agent liability, simply to insure the agent against liability. In this case, the differential between the no-accident wage and the accident wage under agent liability would be greater than the unfunded liability. The principal could then offer the agent the equivalent scheme under enterprise hability. Accordingly, the care levels of the agent would then be identical under the two patterns of hability. 
Alternatively, even though the principal must pay a high no-accident wage under agent liability, it miglit still be optimal for her to set the wage in the event of accident equal to zero. If the pattern of liability is now switched to enterprise liability, the principal will again see the additional costs of the unfunded liability. If the no-accident wage under enterprise liability exceeds the unfunded liability, lowever, the principal will want to decrease rather than increase the level of care the agent takes because the cost to the principal of an accident exceeds the cost of no accident. This circumstance leads to more care under agent than enterprise liability. Tlough it seems both paradoxical and unlikely, I have been unable to exclude it as a logical possibility. If it occurs, it does so because imsuring the agent under agent liability requires raising his wage by at least the unfunded liability across the board; ${ }^{27}$ it may be cheaper for the principal to induce the agent to take too much care.

Regardless of whether the agent takes more or less care under agent liability, the principal would prefer a regime of agent liability. Under any of the postulated payment schemes, the principal cannot enforce full indemnification clauses when the agent's assets are less than the ainount of damage. Thus the wage contract optimal under agent liability must be at least as valuable to the principal as the one optimal under enterprise liability because either lier profits or her utility are at least as high. In fact, if the agent takes different amounts of care under the two patterns of liability, the principal strictly prefers agent hability because under agent liability fewer of the costs of the accidents are shifted froin victim to the principal-agent nexus.

Several observations may be drawn from this analysis. First, one would expect lower prices and higher output under agent liability because the cost of doing business would be less. If the market for the principal's product or service were competitive, the benefits to the principal of agent liability would be passed on to consuiners. Victims would transfer an amount equal to the unfunded liability to consumers. ${ }^{28}$ Second, the agent will prefer enterprise liability to agent liability. Consider, for example, the case in which the agent takes more care under enterprise liability than agent liability. The principal induces the agent to take more care by mcreasing his wage im the event of no acci-

27. To insure the agent means the agent has at least $B$ in the eveut of an accident. To preserve the incentives for care, however, requires that the agent have the same wage differential after insurance as before. This entails raising his wage in the event of an accident.

28. On the other hand, if the victim had a contractual relation with the principal, then the assignment of liability should not make a difference to the principal. Suppose, for instance, that the victim is a consumer of the principal's product. The price of the good should reflect the amount of uncompensated harm that exists under agent liability. Thus, the principal will see the uncompensated damage amount $\mathrm{D}-\mathrm{B}$ in the decreased revenue he would receive under agent hability. 
dent; since it is costly for the agent to take care, his expected wage must rise under enterprise liability. He must, then, be receiving more than his reservation wage to which he was constrained under agent liability. This extra income cannot, im the model, be eliminated by competition because the information restriction on contracts implies that an enterprise cannot effectively enforce an agent's promise to exercise the same amount of care for less pay. The inability of the principal to observe the care level actually taken by the agent means that a promise to take a specific level of care cannot, in practical terms, be enforced. In a world with imperfect monitoring of care that is nore precise than the observation of accident or no accident, it is unclear whether the rent earned by the agent under enterprise liability will be eliminated by competition.

Third, the ability of the principal to screen for more or less careful agents, or the fact that the principal may affect the probability with which accidents occur, does not alter the impact of limited liability on the coinparative merits of agent and enterprise liability. After all, the screening just identifies more or less careful agents; it does not improve their ability to pay judginents. The fact that agents are judgment proof inay distort the screening and care decisions of the principal. Nonetleless, the costs of an agent's conduct under agent liability need not be completely shifted from the victin to the principal-agent nexus.

The limited liability situation here presented may be mitigated in two ways. First, the problein of limited liability may be mitigated by the presence of insurance. If the agent las substantial assets and a healthy dislike for bankruptcy, he is likely to insure against the risk of accidents. Thus, though dainages may exceed an agent's assets, his assets are apt to be sufficient to pay an insurance premium.

Second, the principal may liave limited liability as well. If the principal's assets exceed those of the agent, the above analysis applies with one caveat. Less than socially optinnal levels of care will be taken because neither the agent nor the principal will bear the true costs of the accident. If the principal has fewer assets than the agent, one would expect, im general, enterprise liability to lead to more accidents than agent liability.

In summary, limited liability of agents may lead to differences in levels of care that obtain under the two allocations of liability. Agent hability nay lead to less, equal or more care than enterprise liability. As noted earlier, one would expect that less care will result when agents are close to risk-neutral, poor, and receiving low wages. In most other cases one would expect the principal to insure the agent, and the same levels of care to result under agent liability as under enterprise liability. 


\section{B. The Inability to Offer Optimal Compensation Schemes}

In this Section, I consider the situation in which the restrictions on the principal's ability to write contracts are greater than those assumed in the benchmark case. Most of the discussion is directed at the effect of labor market imperfections on the range of contractual forms a primcipal may offer. This focus should eliminate soine misconceptions about the relation of these imperfections and the prevailing assignment of hability for tort.

In the benchmark case I assumed that the primcipal could circumvent imperfections in the labor market only by offering an optimal compensation scheme that varied appropriately with the presence or absence of an accident. This assumption led to the equivalence of the enterprise and agent liability regimes. Where such optimal schemes are not available, however, the legal regimes would not be equivalent and courts, under agent liability, may be better equipped then the enterprise, under enterprise liability, to induce agents to exercise greater levels of care.

Compensation schemes may be created in a great variety of ways such as through promotion ladders, prospect of raises, chances of being terminated, and bonuses. There are, however, systems under which the principal carmot offer optimal wage scliemes. For example, the principal would be effectively foreclosed from varying the wage with the care of the agent where the agent's salary is strictly determined by seniority. The principal could determine a wage level for any given seniority level but otherwise the agent would receive a fixed income. Even these restricted conditions do not guarantee that the assignment of liability will matter im the benchmark, screening, and work environment cases. If labor has sufficient power to force management to use such a restrictive scheme, it can exert pressure on management to msure agents agaimst liability under agent liability and thus establish the equivalence of the legal regimes.

Of course, if the restrictions are beyond the control of labor and management, the assignment of liability will lead to different care choices by agents. The court can provide an incentive that the principal carmot; therefore, the agent can be induced to take more care under agent liability than under enterprise liability. Conversely, the principal may expend less on screening and on the provision of a safe work environment under agent liability than under enterprise liability. Under agent hability, the primcipal can clioose from a wider range of contracts than under enterprise hability; the potential liability of the agent gives the principal more scope in conditioning wages on the event of an accident. It may be that under agent liability it is cheaper for the principal to reduce accident costs by using the liability system than by screening 
for more careful agents or by providing a safer work environment. It must be the case, therefore, that agent liability produces at least as desirable an outcome as enterprise liability. After all, anything achievable under principal liability can be achieved under agent liability where the constraint does not apply. The principal could guarantee the agent his wage by msuring him against damage. ${ }^{29}$

Public employment provides one possible situation in which the inability to condition wages on employee performance may lead to different and more cautious choices of care under agent liability than enterprise liability. Arguably, the restrictions on wage scliemes are quite great in public employment. The Constitution may require notice and hearing prior to dismissal. Further, many jurisdictions require just cause to fire, a remedy which is expensive to use and frequently unsuccessful. Similarly, "merit" raises may be routinely granted and only rarely and with difficulty withheld. Furthermore, the rigidity in the wage scheme derives only in part from the power of public employees. Some of the restrictions are imposed politically to imsulate public hiring from party pohtics or to satisfy other public policies rather than as a result of the bargaining power of public employees. Thus, public employees might not be able to force the government to insure them under a system of agent liability.

A rule of no indemnification provides a good second exaunple of when a primcipal may not be able to offer an optimal compensation scheme. No mdemnification means that the principal must, under enterprise liability, offer a non-negative wage to the agent in the event of an accident. The principal camiot compensate lierself out of the agent's assets. Although it might be optmial for the principal to fine the agent im the event of an accident, a rule of no indemnification effectively limits fines to the no accident wage, an amount whicl might not be optimal, particularly if the agent is relatively less risk averse than the principal and should thus bear the major part of the accident costs.

\section{Differential Costs of Enforcing Liability Judgments}

In the discussion of the judgment proof agent, the equivalence of the two regmies of liability relied on the fact that the principal had no compensation scheme that was more effective than court imposition of liability on the agent. This result in turn followed from the relatively simple preferences of the agent who cares only about his income, without regard to the date of its receipt or the manner in which it was at-

29. The discrepancy between agent and enterprise liability depends on an asymmetry in the agent's ability to constrain the compensation schemes offered by the principal. Since the agent can enforce a uniform wage under enterprise liabihity, it can successfully bargain for a full insurance against liability under agency liability. 
tained; his level of care; and the risks to which he is exposed. It also required the assumption that the two hability regimes differed only in the assignment of liability. However, it may be inore costly to victims to enforce a claim under agent liability. I shall argue that this differential suggests inore care is taken under enterprise liability.

There are three reasons why the enforcement of enterprise liability is less costly than the enforcement of agent liability. First, though under agent hability a successful plaintiff would have access to the judgment proof agent's future stream of imcome, plaintiffs may be less likely to initiate suits against judgment proof agents than against solvent principals. The plaintiff's expectations of recovery may differ. Second, the value to the plaintiff of an award collected out of the agent's future receipts is less than the value of an immediate award from the principal. The plaintiff may liave time preferences for money and the legal interest rate on judgments may be less than the market rate of interest. Consequently, the plaintiff would prefer the money sooner. Third, the costs of collection against the agent are apt to be higher than against the principal. The plaintiff inay have to keep the agent under observation to see when the award can be paid or he may have to levy and execute at several distinct points in time. Thus, the principal nnay be a inore effective ineans of communicating the incentive to the agent because enforcement and admimistration costs are lower under enterprise liability.

The frequency with which legitimate suits are brought will affect the levels of care taken by agents because the liability regime coinmunicates the costs of accidents to the principal-agent nexus only through actual liability awards. Additional costs of enforcing claims under agent liability implies that agents will sue less frequently on neritorious claims under agent liability than under enterprise hability.

\section{Agent Stigmatization}

Aside froin pecuniary incentives under the two legal regimes, agent levels of care inay be influenced by nonmonetary differences between the regimes. Agents may be concerned witl more than income, care, and risk. They inay, in particular, be concerned about their reputations. If stigma attaches to civil judgments, agent liability may yield more care than enterprise liability.

Career opportunities with different employers may vary with the assignment of liability. To argue that the assignment of liability matters means either that the nominal assignment of liability governs decisions rather than the actual assignment or that the agent cares about 
the assignment for nonpecumiary reasons such as stigma. ${ }^{30}$ Stigma may affect the agent's job mobility. A bad liability record may make an agent less employable. This argument depends upon principals relying on the nominal assignment of liability rather than on the actual assignment of responsibility for payment. Thus a prospective principal could not find out under enterprise liability that a particular agent had acted carelessly and caused a variety of mjuries charged to a prior employee while that information would be discoverable under an agent liability scheme.

\section{E. Multiple Agents}

Courts may have difficulty identifymg a causally responsible agent if the events leading to mjury originated im a largc, complex organization. Thus, even under a scheme of strict liability, agents might escape responsibility because the plamtiff cannot prove a causal link. Under enterprise liability the plaimtiff, however, might succeed in her suit because she can attribute the cause to the enterprise but not to any particular individual or division of it. Under these circumstances, shiftimg from agent to enterprise liability will lead to a greater level of care if first, the principal can affect the probability of injury by her arrangement of the work environment; second, the principal may, at some cost, screen agents on the basis of carefulness; or third, the principal can identify the causally responsible agent more readily than courts can.

In each of these three cases, the shift to enterprise liability will lead to a decrease in the number of mjuries. When courts cannot attribute liability to the responsible agent, the pricipal need not compensate the agent for the damage done. The principal would have little incentive to search for more careful agents or to provide a less dangerous work environment. Under enterprise liability the principal inust bear the costs of the mjuries and can take proper and effective action to limit them. The principal is not constrained as courts are to impose liability on a single imdividual who is causally responsible for the wrong. The principal may, for instance, penalize everyone in a work group if the group can be causally related to the injury but no member of the group can be singled out.

The discrepancy between the two regines of liability arises in part from the imstitutional constraints on the courts. In general, courts will not impose liability on an agent greater than the amount of actual damage. If courts abandoned this constraint, agents would be indifferent to risk and courts could identify the responsible agent some fraction $R$ (less than 1 and greater than 0 ) of the time, inflatimg the actual damages

30. Baxter, supra note 11, imphicitly assumes a model of stigma or one in which the nominal assignment matters for some other reason. 
by $1 / R$ would induce the agent to take the saine care level as he would take if the courts could always attribute responsibility and the principal would offer the saine compensation scheine. ${ }^{31}$ If the agent is averse to risk, complications arise. If the courts allowed damage awards greater than actual damages, they could lold the principal to the same level of utility she achieves in a scheme of agent liability witl perfect attribution of responsibility. But neither the compensation scheme nor level of care under imperfect attribution will be identical to their counterparts under perfect attribution. If, for example, the principal is indifferent to risk, either the wage in the event of an accident inust fall or the level of care taken by the agent will drop. Furtliernore, as the fraction of the time the courts attribute liability falls, the amount of damages that the court must impose to produce equivalent beliavior rises. At some point, a previously solvent agent would be unable to meet the potential liability. Hence, if courts liave great difficulty in attributing liability to particular agents, the problem of limited liability would arise; the courts would do better to adhere to the actual damages rule and assign liability to the enterprise.

\section{F. Different Accuracy of Observation}

One might argue that the courts are less able than the principal to observe accurately the precautions taken by an agent. If the responsibility of the principal under enterprise liability depends upon proof of the responsibility of the agent, it is hard to see how the discrepancy between the ability of court and principal to observe the agent's beliavior matters. If, however, the courts find it easier to impose liability under enterprise than under agent liability and the inability to observe resulted im less imposition of liability under agent liability, enterprise hability will lead to the agent taking more care for tlie saine reasons outlined in the inultiple agent case discussed above.

It is difficult to see why courts slould be able to impose liability on principals more frequently and with greater accuracy than on agents. Perhaps juries are more likely to find for individual defendants than agamst corporate ones. Assuming, however, that a difference in the court's ability to impose liability exists, imposing liability on the enterprise would induce the agent to take more care. The analysis liere parallels the analysis of the inultiple agent case. Given a constant care level, the mability to identify a single responsible agent would lead to fewer findings of liability under agent liability than under enterprise

31. If the agent is risk neutral, the principal does not insure him against liability. Therefore, either the no-indemnification rule assumed earlier must be waived or the courts must allow the compensation to vary by the amount of the damage award. 
liability. The analysis of the prior Section, as the analysis here, depends only on the differential rate of attribution of liability.

\section{$\mathrm{V}$ \\ Caveats and Qualifications}

The analysis outlined above suggests that the assignment of liability between agent and enterprise will alter the mcentives of agents to take care only in limited circumstances. The level of care was not responsive to the conflicting imterests of principal and agent, or to the ability of the principal to screen or to provide safer work environments. Only under the circumstances in which courts cannot attribute causal responsibility to agents, more restrictions are placed on the contractual forms available to principals, the liability regimes differ in more than the assignment of hability, or in which the agent has limited liability, may the assignment of liability inatter.

In this Part, I will discuss several additional aspects and implications of the analysis which require further comment. In Section A, I will analyze inore thoroughly the model's reliance on the assumption that the labor inarket transfers imformation efficiently, and that agents and principals are utility maximizers. In Section B, I will discuss the implications of the analysis for situations where the care taken by the agent affects the output of the enterprise. Fimally, in Section C, I will discuss the implications of the analysis for the distinction between independent contractors and servants.

\section{A. The Efficiency of the Labor Market and Utility Maximization}

This Section considers the assumptions underlying the benclimark case and suggests that they are reasonable. First, as noted earlier, the analysis rests on the manner in which labor markets transmit information about the costs of care and of accidents. The two regimes of liability lead to equivalent outcoines because, annong other things, the imposition of liability on one party or the other does not alter the ability of labor inarkets to transmit information about care. One might argue that the liability regime alters other aspects of the labor market that are relevant to the choice of care level and contracts. These arguinents will be raised below.

Consider the benchmark case. Here it is difficult to see how the assignment of liability affects the labor market's ability to transmit information. One potential impact of changing the legal regime arises from the different distributions of wealth to which the two legal regimes give rise. Under agent hability employees are nominally im a 
worse bargaining position than they are under enterprise liability. ${ }^{32}$ No one doubts that this has a wealth effect; that is, that employees might be poorer under agent liability than under enterprise liability. Whether the different wealth position alters the efficiency of the outcomes is more problematic. ${ }^{33}$ However, the wealth transfer that arises in a shift from enterprise to agent liability does not alter the principal's desire to minimize his wage bill, though it may change the dynamics of the bargaining gaine.

A second apparent difficulty with the argument for symmetry in the two legal regimes stens from the unreasonable assumption that agents perceive with accuracy the costs of accidents. Agents may im fact misperceive the costs of accidents. In particular they may think accidents less likely than they actually are. If agents misperceive the costs of accidents and enterprises do not, the different legal regimes will lead to different levels of care. Only enterprise liability will lead to an appropriate level. If we imagine, however, the situation recurring over time, one would expect agents to learn the costs of accidents and eventually to deinand appropriate compensation for the risks. Thus, the arguinent froin agent misperceptions requires one to identify the mechanisin that sustams these misperceptions over time.

Third, the analysis did not consider the fact that the principalagent relation is repeated over time. The formal analysis assumed that the agent worked once and then stopped. Of course, the agent generally performs the saine set of tasks repeatedly and the principal has the opportunity to observe his agent's behavior over long periods of timie. The length of the primcipal-agent relation suggests that the enterprise can observe care more accurately than the courts but this superior ability to inonitor is symmetric with respect to legal regimes.

Finally, the analysis assumes that both principal and agent maximize expected utility. These assumptions might be violated in two ways: the principal (or agent) might not maximize the objective function used in the appendix and implicitly in the text, or the principal (or agent) might be boundedly rational and hence use some rule of thumb rather than optimal rule in setting wages. Of these two potential diffculties the forner is less serious. Even if enterprises have complex, non-economic objectives, it seems likely that these objectives are not altered by changes in the liability scheme. If a corporation or a public agency does not care about the injuries it inflicts on third parties under

32. By "efficiency" I mean here the solution to the optimization problem posed in the article. The variables we are looking at are the optimal wage contract and the induced level of care. It may be that the bargaining process prevents principals from offering the optimal contract.

33. See Mashaw, supra note 12; Schuck, supra note 14. 
one regime of liability it will not care under the alternative regime. Labor markets slow the costs of accidents under both regimes.

If principals or agents do not optimize but use rules of thumb instead, the analysis of the comparative effects of legal regimes requires one to specify the particular rules of thumb used. For the choice of legal regime to matter, however, the rule of thumb will have to depend on some variable that does change when the legal regime changes.

\section{B. When the Agent Care Level Affects Productivity}

So far the analysis has considered only those situations in which the agent's care level has no effect on productivity. Let us now examine what occurs if the activity that causes the injury might also affect the level of output for the principal. Two effects on output are possible: positive and negative correlation. Presumably, we are most interested in those cases in which higher accident costs are correlated with greater output, for in these cases the principal lias an incentive to encourage careless behavior. Such encouragement will certainly occur if neither principal nor agent is liable for accident costs. If accident costs are negatively correlated with output the principal will have an incentive to discourage aceidents regardless of the damages imposed by the accident.

The legal grounds for liability for unrelated accidents (no connection between output and injury) differs from the grounds for hability for related accidents (output and injury related). When a related accident positively correlated with output occurs, the courts are more likely to assign liability to the principal for two reasons. Both reasons rely on the principal's direct benefit from the increased number of accidents, and the principal's desire for more profit. First, the agent's reason for being careless may derive from the principal's profit motive. There is thus a causal link between accident and principal. Second, the profit motive allows one to impute more easily to the principal an intent of negligence.

While an unrelated accident might result from 'careless' hiring procedures by the principal or froin inadequate safeguards on the part of the principal, she does not appear to benefit directly from the activity which leads to the accident. The legal grounds for lolding the principal liable for at least some unrelated accidents are therefore more controversial than those for lolding her liable for related accidents. ${ }^{34}$ In fact, the Supreme Court, $\mathrm{m}$ extending enterprise liability to ununicipali-

34. This can only be addressed with an adequate theory of bargaining, which, unfortunately, does not exist. See Cooter \& Kornhauser, Can Litigation Improve the Law Without the Help of Judges?, 9 J. LeGAL STUd. 139 (1980). 
ties, refused to extend it to situations of purely vicarious liability. ${ }^{35}$ Does the nature of the relation between care and productivity alter the analysis?

If the agent has sufficient assets to meet all the damages caused by his actions, the analysis remains the same. One must only note that, when care is related to productivity, the "damages" resulting from the care taken by the agent include not only the damages to third parties but also the effect on profits to the principal. Tlius, if more care leads to more productivity, the margmal benefits derived from more care imclude both the marginal reduction in accident costs and the mcrease im productivity. Of course the principal will be aware of the margimal reduction in profits from too little care and so will choose a compensation scheme that encourages the agent to take more care. If more care decreases productivity, the marginal benefits derived from more care are less than the marginal reduction im accident costs. Consequently, the principal will choose a cornpensation scheme that encourages the agent to take lcss care than he would absent the correlation between care and output. If the agent has limited assets, lie is more likely to be judgment proof if more care lcads to more productivity, because net damages which mclude lost profits are greater. If less care leads to greater productivity and the agent's assets are insufficient to pay damages, the principal derives greater benefit from a system of agent liability.

In any case, the analysis does not change im any fundainental way when the technical relation between accident prevention and productivity changes. The legal distmction between the types of accidents must therefore rest on soine non-economic ground.

\section{Independent Contractors}

Fimally, the implications of the inodel for the legal basis of the treatment of imdependent contractors deserves some comment. The law distinguishes between independent contractors and employees. An enterprise is not liable for the torts of its independent contractors, but it may be liable for the torts of its employees. The analysis of Part III provides a possible rationale for this distinction. The rationale may rest on the reasonable assumption that independent contractors are likely to be risk neutral while employees are likely to be risk averse. ${ }^{36}$

If agents do not care about risk, the principal can give them full incentives to take the appropriate level of care by imposing on agents the full consequences of their acts. The principal's mability to monitor agent care now has no adverse consequences; the agent sees all the costs

35. See supra note 24. See also Calabresi, Some Thoughts on Risk Distribution and the Law of Torts, 70 YALE L.J. 499 (1961).

36. Monell v. Department of Social Services, 436 U.S. 658, 691 (1978). 
and benefits of taking care himself. Nor are any additional costs imposed because the agent dislikes risk. ${ }^{37}$ Thus, assigning liability to the principal requires her to contract with and possibly to sue for indemnification from her agent.

On the other hand, if the agent is risk averse, the optimal compensation scheme will split the risk between principal and agent. The allocation could be done either through a contract of partial indemnification or through the compensation sclieme of the principal. The assignment of liability to independent contractors would thus appear to lessen the litigation and contracting costs by allowing the liability to rest on the appropriate, risk neutral-party.

\section{VI \\ The Distinction Between Private and Public ENTERPRISE: NORMATIVE IMPLICATIONS}

Thus far, the analysis has addressed only the descriptive question of whether the level of care and lience accident costs would differ under the two regimes of liability. It has not addressed the normative implications of the findings. To do so requires identification of the normative criteria by whicl the choice will be made. For the brief discussion that follows I shall assnme that tort law seeks to further some weighted combination of two goals: efficiency and compensation of victims. I shall conclude that liability should be imposed on the private enterprise. The analysis offers less clear cut guidance in the public enterprise case. While we may conclude that official immumity is unjustified, the choice between enterprise and agent liability rests on a variety of einpirical and normative concerns, discussed below, that lie outside the scope of the preceding analysis.

Before proceeding, we must define efficiency more precisely. To use the conventional criterion of Pareto optimality we inust consider the preferences of three classes of actors: enterprises, agents and victims. A rule of liability will be Pareto optimal if none of the actors can be inade (from lier own perspective) better off without making another actor worse off. To begim, assume that the victim is fully compensated under each assignment of liability; then the welfare of the victim can be

37. The legal distinction between independent contractor and servant suggests a different reason for the difference in hability status of the principal. The principal neither controls nor has the right to control the physical conduct of her independent contractors while she does control or has the right to control the physical conduct of her servants. The legal difference might then rest on a behef that differences in the cost of observing the level of care taken affect the desirability of the two legal regimes. The analysis of Part III deinonstrates that such a belief is unwarranted. If principals are better monitors of servants than courts are, but not better momitors of independent contractors, one would expect servants to take more care at the same task than independent contractors, regardless of the legal regime. Both servants and contractors benefit froin more accurate observation of care but they benefit equally under the two assignments of liability. 
ignored and we can attend solely to the efficiency impact of the rules as between principal and agent.

If the principal is an individual, Pareto optimality is a plausible criterion to apply. If the principal is an institution, however, the application of Pareto optimality as a criterion becoines a bit inore probleinatic. One might be concerned about the goal of the institution since whether or not the institution is made better off from its "own point of view" depends on the standard against which it measures its perfornance. Implicitly, the above analysis assumed that principals, whether individuals or institutions, cared only about money costs and risk. Preferences of this sort are compatible with Pareto optimality since an institution that maximized profits or minimized costs would be acting in a nanner consistent with achieving Pareto optimality for all individuals in the society and distributional goals, as distinct from coinpensation goals, could be handled by taxation scheines. An institutional goal such as maximizing institutional size is not obviously coincident with achieving Pareto optimahty among individuals in society.

The normative imphications of the analysis of Parts III and IV, therefore, depend in part on the plausibility that the principal had the assumed preferences. The analysis suggests differences between public and private enterprise.

Private business, it is generally assumed, seeks to maximize its profits; deviations from profit-making strategies are likely to be sanctioned by the narket. Thus, the analysis of Parts III and IV supports imposition of private enterprise hability on several grounds. First, in those instances in which enterprise and agent hability would lead to the saine levels of care in the absence of transaction costs, we would expect the transaction costs of coinpensation to be less under enterprise liability. Enterprise hability will therefore better approximate the zero transaction cost optimuin. Second, in the limited liability case, enterprise hability is apt to be both more efficient and to provide inore compensation. It was argued that, in the presence of limited liability, agents are apt to take less care under agent liability; the agents will also be taking too little care from an efficiency viewpoint. Switching to enterprise liability will increase care and compensation. Third, there is some reason to beheve that the enterprise can better identify responsible actors than courts; again enterprise hability will induce both unore efficient care and inore coinpensation. Fourth, soine probleins not addressed by the inodel, such as the fact that agents imight underestimate the risks of causing damage, suggest that enterprise hability would be more efficient.

The imphications of the analysis for public enterprise are unore anbiguous. As noted above, agent liability nay add flexibility to wage 
scales made rigid by political considerations. Thus, if agents are not judgment proof, agent liability would lead to more efficient outcomes and to equal amounts of compensation for victims. In the presence of limited hability or difficulties in the judicial attribution of responsibility, on the other hand, enterprise liability would be preferred on compensation grounds. It might seem, therefore, that I have argued for the elimination of immunity for government officials and the imposition of agent hability. The argument, however, is incomplete. Victims apparently prefer to sue enterprises over individuals; unless public agencies seek indemnity from their employees or plaintiffs sue both agent and agency and seek satisfaction of their judginent first from the agent, the appropriate incentive would not be comniunicated to the agent. Thus, the choice between enterprise hability without official immunity and agent hability with sovereign immunity might easily mvolve a tradeoff between efficiency and compensation goals. The agent hability regime favors efficiency while the enterprise liability reginie favors compensation.

There seems to be, however, no economic efficiency justification for official immunity. The debate over sovereign and official immunity in public enterprise does not turn on the question of different care levels induced by enterprise and agent hability. Rather, the question turns on two other facts: the public enterprise's goals differ from society's goals and the assignment of hability to the principal-agent nexus rather than the victim is asymmetrical.

First, under the analysis of Parts III and IV, whatever the objcctive of the public enterprise, the assignment of liability will not alter its behavior or the behavior of its agents with respect to expected injury costs. To the extent, however, that the objective of the cnterprise differs from the objective of the society we might desire different behavior. That is, the imposition of liability on the government enterprise or its agents may not be adequate to conform its behavior to the social objective. For example, assunne that government enterprise wishes to maximize the number of its employees. Charging to it the costs of its employees' torts inay limit the size of its staff but would not adequately bring its behavior into accord with social objectives. Some other remedy will be required.

If the objective of the principal deviates froin that of society, a host of problems arise. For instance, the principal and the agent niay collude agamst the court. Such collusion would not occur if the principal and the court both sought to promote social objectives. If they did collude, any advantages the primcipal might have in observing or controlling the agent might not be exploited. Further, the courts night be better able to achieve the social objective if they relaxed the rule con- 
fining liability to actual damages. Thus, the analysis of the imposition of hability would grow more complex.

Second, the government enterprise may conscientiously seek to maximize its conception of the social objective. That may differ from the conception articulated by the court. Again, the assignment of liability will not matter; the imposition of liability - the question whether the principal-agent nexus ought to be hable at all-does matter. An unwillingness to impose hability implies a behef that the enterprise's conception of the social good should prevail over the court's. Imposition of hability entails the converse preference. The dilemma is not on whom to impose hability but which branch of government should decide the social objective.

If the principal holds precisely the saine objectives as the courts, even the imposition of hability will not matter. The principal would impose the appropriate amount of liability on the agent to achieve the shared goals. The distinction between government and private enterprise raised by both Mashaw and Schuck therefore broaches two very important problems ${ }^{38}$. How do we fornulate the objectives and measure the achievement of governmental enterprises? And, given that no bureaucracy 'selflessly' acts to promote social objectives, how best do we structure mcentives to government enterprises so as to achieve best the social objective? Answers to these questions will determine whether we impose liability on the principal-agent nexus rather than on the victim. The answers should not determine whether to assign hability to the principal or the agent once the decision has been made to impose hability on the principal-agent nexus. In a wide variety of circumstances, the assignment will not alter behavior. It may insure compensation of victims or provide superior spreading of the risk.

A related concern of Mashaw and Schuck is the bias in errors that agents faced with hability may make. This concern arises because they argue that hability leads to less vigorous decisionmaking on the part of officials. While this argument is sometimes taken as an argument for official immunity, it is actually directed at the pattern of hability imposed on the principal-agent nexus as a whole. Officials may expose themselves to less liability by making one type of mistake rather than another for two distinct reasons. One set of victims is less likely to observe the damage than another. For instance, someone physically beaten in the course of a wrongful arrest is apt to notice the injury while persons subject to illegal wiretaps and covert harassment by pohice agencies may never discover the invasion of privacy. Alternatively, the law may not impose hability on the principal-agent nexus in a

38. See Shavell, Risk Sharing and Incentives in the Principal and Agent Relationship, 10 BELL J. ECON. 55 (1979); Holmstrom, Moral Hazard and Observability, 10 BeLL J. ECON. 74 (1979). 
"symmetric" fashion. Consider police on the beat facing an ambiguous street situation. If they imtervene, they may face potential hability for wrongful arrest or for misconduct in the course of the arrest. Failure to intervene, however, may not subject them to any risk of liability both because no one may notice their failure to intervene and because tort law is inuch more hesitant in imposing duties on police for inaction than it is for active misconduct. Neither of these asymmetries in the potential liability of officials results from the absence of official immunity. It is not clear why an enterprise that conscientiously seeks to fulfill its mission under enterprise liability will do so under agent liability as well. A conscientious principal will structure its conipensation scheme under agent liability to penalize errors of inaction appropriately. Of course, if the principal camiot, like the court, observe these errors, no compensation schene under either assignment of hability will create the appropriate incentives. Even if the enterprise's objectives differ from the social objectives, they will differ under both liability regimes. The problen then lies in the discrepancy betwcen social and enterprise goals.

\section{CONCLUSION}

This Article has examined low the assignnent of liability to principal or to agent affects the level of care taken in activities hazardous to third parties. Conditions under which the assignment of liability has no impact on care and those under which the assignment may affect care levels were nuodeled. Many of the conditions that may affect care levels plausibly represent real life conditions. Limited hability, multiphicity of agents, and differences between court and enterprise ability to monitor care levels are common characteristics of bureaucratic activity. This paper's model suggests that in the private sector, enterprise liability produces greater levels of care. The analysis also covered the independent contractor-servant and the vicarious-nonvicarious liability distmctions. The question of low the regime of liability affects the level of care taken illuminates but does not conclude the issues. Understanding the effects of different legal regimes on care levels is necessary to the formulation of sound legal policy but it is not sufficient.

On the otlier hand, the analysis of the decision to assign hability either to the public enterprise or the public official similarly did not yield a clear cut conclusion. Rather, the assigninent of liability issue either did not turn solely on the relative levels of care or was not the crucial question. The key question with respect to public enterprise is whether should we impose liability on the public enterprise or public servant at all. 


\section{APPENDIX}

This Appendix formulates and proves more rigorously the statements made in the text. The formal treatment deals inost extensively with the case in which the agent's choice of care does not affect at all the agent's productivity.

Section A of this Appendix formulates the inathernatical proofs. The end of that Section indicates how the problein may be reformulated to handle the more complex situation in which care and output are related. Section B then discusses and criticizes a recent treatment of the primcipal-agent hability questions considered in this article.

\section{A. Mathematical Proofs}

\section{Overview}

The mathematical model developed in this Section derives primarily froin that used by Holmstrom. ${ }^{39}$ The structure of the mathematical formulation is paradigmatically economic.

The model assuines that the primcipal inaximizes his utility subject to various constraints. Modification in these constraints represents the additional "transaction costs" analyzed in the text. To be more precise:

(1) The restrictions on the primcipal's choice of contract form are embedded in the choice variables open to the principal to maximize her utility. Thus, she maximizes her (constrained) utility over choices of $W_{0}$ and $W_{D}$. In the screening case and the work environinent case the primcipal also chooses the screening levels or a care level, respectively.

(2) The conflict of interest between principal and agent einerges from the fact that the agent's utility depends on his care as well as his income while the principal's utility does not depend on agent care directly.

(3) The labor inarket is modelled in the simple constraint that the principal has to offer a wage contract that provides the agent with at least his reservation utility. (This is the constraint with Lagrangean mültiplier $\mathrm{k}_{1}$ ).

(4) The inability of the principal to inonitor the care of the agent appears in the fact that the principal's clioice variables do not include the agent's care level. Rather, the principal chooses a wage contract subject to the additional constraint that the agent will select his care level optimally, given the wage contract. (This is the constraint with Lagrangean inultiplier $\mathrm{k}_{2}$ ).

(5) The liability regime is modelled by the placement of the nominal damages $\mathrm{D}$ in the appropriate utility function.

39. Holmstrom, supra note 38 . 
(6) Limited liabilty is modelled by introducing a variable B representing agent assets and adjusting the equations to insure that the agent always has at least zero wealth in every state of the world.

(7) The multiphicity of agents problein is modelled by analyzing how the multiphicity affects the probability of paying damages.

Most of the proofs have a simple form. I first compare the firstorder conditions of the two maximization problems faced by the principal-one under agent-liability and one under enterprise liability. I then show that a suitably modified solution to one problein both satisfies the first order conditions of the second problem and is in fact maximal (as opposed to minimal) for that problem.

\section{Notation}

The following notation will be used:

D

$\mathrm{x}$

$\mathrm{y}$

$\mathrm{p}(\mathrm{x})$

$\mathrm{p}(\mathrm{x}, \mathrm{y})$

$\mathrm{p}_{\mathrm{i}}(\mathrm{x}, \mathrm{y})$

S

$\mathrm{g}(\mathrm{s})$

$\mathrm{W}_{0}$

$\mathrm{W}_{\mathrm{D}}$

$\mathrm{U}(\mathrm{W})$

$\mathrm{V}(\mathrm{W})-\mathrm{C}(\mathrm{x})$ the agent's utility;

separable in money $\mathrm{V}^{\prime} \geqslant 0, \mathrm{~V}^{\prime \prime}<0$

and care

$C^{\prime} \geqslant 0, C^{\prime \prime}>0$

$\overline{\mathrm{V}}$

B

$\mathrm{L}^{\mathbf{A}}$

$\mathrm{L}^{\mathrm{P}}$ dent the care level of the agent $(x \geqslant 0)$ only on agent care on both agent and principal care where $i$ is either $x$ or $y$.

the cost of screening when cost $s$ is incurred.

the wage in the event of accident

the agent's reservation utility

the agent's initial assets

the Lagrangean under agent liability the amount of damage (and liability) caused by an accithe care level of the primcipal $(y \geqslant 0)$ (when appropriate) the probability of no accident if the probability depends the probability of no accident if the probability depends

The partial derivative of $p$ with respect to variable $i$,

the probability that a inore careful agent will be chosen

the wage in the event of no accident

the primcipal's utility function $U^{\prime} \geqslant 0, U^{\prime \prime}<0$

the Lagrangean under primcipal liability 


\section{Formulas}

a. The Benchmark Case

i. Agent Liability

Under agent liability, the principal maximizes his utility

$$
p(x) U\left(-W_{0}\right)+(1-p(x)) U\left(-W_{D}\right)
$$

subject to the restriction that the agent must enjoy a utility at least as favorable as the reservation utility:

$$
\mathrm{p}(\mathrm{x}) \mathrm{V}\left(\mathrm{W}_{0}\right)+(1-\mathrm{p}(\mathrm{x})) \mathrm{V}\left(\mathrm{W}_{\mathrm{D}}-\mathrm{D}\right)-\mathrm{C}(\mathrm{x}) \geqslant \overline{\mathrm{V}}
$$

and subject to the restriction that the agent trades off imcreased money for increased care:

$$
\mathrm{p}_{\mathrm{x}}(\mathrm{x})\left(\mathrm{V}\left(\mathrm{W}_{0}\right)-\mathrm{V}\left(\mathrm{W}_{\mathrm{D}}-\mathrm{D}\right)\right)-\mathrm{C}^{\prime}(\mathrm{x})=0
$$

We may forin the Lagrangean $L^{A}$ :

$$
\begin{aligned}
\mathrm{L}^{\mathrm{A}} & =\mathrm{p}(\mathrm{x}) \mathrm{U}\left(-\mathrm{W}_{0}\right)+(1-\mathrm{p}(\mathrm{x})) \mathrm{U}\left(-\mathrm{W}_{\mathrm{D}}\right) \\
& +\mathrm{k}_{1}\left(\mathrm{p}(\mathrm{x}) \mathrm{V}\left(\mathrm{W}_{0}\right)+(1-\mathrm{p}(\mathrm{x})) \mathrm{V}\left(\mathrm{W}_{\mathrm{D}}-\mathrm{D}\right)-\mathrm{C}(\mathrm{x})-\overline{\mathrm{V}}\right) \\
& +\mathrm{k}_{2}\left(\mathrm{p}_{\mathrm{x}}(\mathrm{x})\left(\mathrm{V}\left(\mathrm{W}_{0}\right)-\mathrm{V}\left(\mathrm{W}_{\mathrm{D}}-\mathrm{D}\right)\right)-\mathrm{C}^{\prime}(\mathrm{x})\right)
\end{aligned}
$$

The first-order conditions are:

$$
\begin{aligned}
& \mathrm{U}^{\prime}\left(-\mathrm{W}_{0}\right) / \mathrm{V}^{\prime}\left(\mathrm{W}_{0}\right)=\mathrm{k}_{1}+\mathrm{k}_{2} \mathrm{p}_{\mathrm{x}} / \mathrm{p} \\
& \mathrm{U}^{\prime}\left(-\mathrm{W}_{\mathrm{D}}\right) / \mathrm{V}^{\prime}\left(\mathrm{W}_{\mathrm{D}}-\mathrm{D}\right)=\mathrm{k}_{1}-\mathrm{k}_{2} \mathrm{p}_{\mathrm{x}} /(1-\mathrm{p}) \\
& \mathrm{p}(\mathrm{x}) \mathrm{V}\left(\mathrm{W}_{0}\right)+(1-\mathrm{p}(\mathrm{x})) \mathrm{V}\left(\mathrm{W}_{\mathrm{D}}-\mathrm{D}\right)-\mathrm{C}(\mathrm{x})=\overline{\mathrm{V}} \\
& \mathrm{p}_{\mathrm{x}}(\mathrm{x})\left(\mathrm{V}\left(\mathrm{W}_{0}\right)-\mathrm{V}\left(\mathrm{W}_{\mathrm{D}}-\mathrm{D}\right)\right)=\mathrm{C}^{\prime}(\mathrm{x}) \\
& \mathrm{p}_{\mathrm{x}}\left(\mathrm{U}\left(-\mathrm{W}_{0}\right)-\mathrm{U}\left(-\mathrm{W}_{\mathrm{D}}\right)\right)+\mathrm{k}_{2}\left(\mathrm{p}_{\mathrm{xx}}\left(\mathrm{V}\left(\mathrm{W}_{0}\right)-\mathrm{V}\left(\mathrm{W}_{\mathrm{D}}-\mathrm{D}\right)\right)-\right. \\
& \mathrm{C}^{\prime \prime}(\mathrm{x})=0
\end{aligned}
$$

Let $\left(\mathrm{W}_{0}^{\mathrm{A}}, \mathrm{W}_{\mathrm{D}}^{\mathrm{A}}, \mathrm{x}^{\mathrm{A}}\right)$ solve this problem.

\section{b. Enterprise Liability}

Under enterprise liability

The principal maximizes over $\left(\mathrm{W}_{0}, \mathrm{~W}_{\mathrm{D}}, \mathrm{x}\right)$ 


$$
\begin{aligned}
L^{P}= & p(x) U\left(-W_{0}\right)+(1-p(x)) U\left(-W_{D}-D\right) \\
& +k_{1}\left(p(x) V\left(W_{0}\right)+(1-p(x)) V\left(W_{D}\right)-C(x)-\bar{V}\right) \\
& +k_{2}\left(p_{x}\left(V\left(W_{0}\right)-V\left(W_{D}\right)\right)-C^{\prime}(x)\right)
\end{aligned}
$$

The first-order conditions are:

$$
\begin{aligned}
& \mathrm{U}^{\prime}\left(-\mathrm{W}_{0}\right) / \mathrm{V}^{\prime}\left(\mathrm{W}_{0}\right)=\mathrm{k}_{1}+\mathrm{k}_{2} \mathrm{p}_{\mathrm{x}} / \mathrm{p} \\
& \mathrm{U}^{\prime}\left(-\mathrm{W}_{\mathrm{D}}-\mathrm{D}\right) / \mathrm{V}^{\prime}\left(\mathrm{W}_{\mathrm{D}}\right)=\mathrm{k}_{1}-\mathrm{k}_{2} \mathrm{p}_{\mathrm{x}} /(1-\mathrm{p}) \\
& \mathrm{p}(\mathrm{x}) \mathrm{V}\left(\mathrm{W}_{0}\right)+(1-\mathrm{p}) \mathrm{V}\left(\mathrm{W}_{\mathrm{D}}\right)-\mathrm{C}(\mathrm{x})=\overline{\mathrm{V}} \\
& \mathrm{p}_{\mathrm{x}}\left(\mathrm{V}\left(\mathrm{W}_{0}\right)-\mathrm{V}\left(\mathrm{W}_{\mathrm{D}}\right)\right)=\mathrm{C}^{\prime}(\mathrm{x}) \\
& \mathrm{p}_{\mathrm{x}}\left(\mathrm{U}\left(-\mathrm{W}_{0}\right)-\mathrm{U}\left(-\mathrm{W}_{\mathrm{D}}-\mathrm{D}\right)\right)+\mathrm{k}_{2}\left(\mathrm{p}_{\mathrm{xx}}\left(\mathrm{V}^{\prime}\left(\mathrm{W}_{0}\right)-\mathrm{V}\left(\mathrm{W}_{\mathrm{D}}\right)\right)-\right. \\
& \left.\mathrm{C}^{\prime \prime}(\mathrm{x})\right)=0
\end{aligned}
$$

Let $\left(W_{0}^{P}, W_{D}^{P}, x^{P}\right)$ maximize $L^{P}$.

\section{Proposition 1:}

(a) If $\left(\mathrm{W}_{0}^{\mathrm{A}}, \mathrm{W}_{\mathrm{D}}^{\mathrm{A}}, \mathrm{x}^{\mathrm{A}}\right)$ maximizes. $\mathrm{L}^{\mathrm{A}}$ then $\left(\mathrm{W}_{0}^{\mathrm{A}}, \mathrm{W}_{\mathrm{D}}^{\mathrm{A}}-\mathrm{D}, \mathrm{x}^{\mathrm{A}}\right)$ maximizes $\mathrm{L}^{\mathbf{P}}$.

(b) If $\left(\mathrm{W}_{0}^{\mathrm{P}}, \mathrm{P}_{\mathrm{D}}^{\mathrm{P}}, \mathrm{X}^{\mathrm{P}}\right)$ maximizes $\mathrm{L}^{\mathrm{P}}$ then $\left(\mathrm{W}_{0}^{\mathrm{P}}, \mathrm{W}_{\mathrm{D}}^{\mathrm{P}}+\mathrm{D}, \mathrm{x}^{\mathrm{P}}\right)$ maximizes $\mathrm{L}^{\mathrm{A}}$.

Proof: Part (a) is proved. The proof for part (b) is analogous.

$\left(W_{0}^{A}, W_{D}^{A}-D, x^{A}\right)$ satisfies the first order conditions of $L^{P}$. We show that $\left(\mathrm{W}_{0}^{\mathrm{A}}, \mathrm{W}_{\mathrm{D}}^{\mathrm{A}}-\mathrm{D}, \mathrm{x}^{\mathrm{A}}\right)$ is a maximum by proof by contradiction.

Suppose

$$
\begin{aligned}
& L^{P}\left(W_{0}, W_{D}, x\right)>L^{P}\left(W_{0}^{A}, W_{D}^{A}-D, x^{A}\right) \\
& L^{P}\left(W_{0}, W_{D}, x\right)=L^{A}\left(W_{0}, W_{D}+D, x\right) \\
& L^{A}\left(W_{0}, W_{D}+D, x\right)>L^{P}\left(W_{0}^{A}, W_{D}^{A}-D, x^{A}\right) \\
& L^{A}\left(W_{0}, W_{D}+D, x\right)>L^{A}\left(W_{0}^{A}, W_{D}^{A}, x^{A}\right)
\end{aligned}
$$

which is a contradiction of the maximality of $\left(\mathrm{W}_{0}^{\mathrm{A}}, \mathrm{W}_{0}^{\mathrm{A}}, \mathrm{x}^{\mathrm{A}}\right)$. Q.E.D. 


\section{b. The Limited Liability Case}

The Benchmark case is modified only by the additional constraints, in both $L^{A}$ and $L^{P}$, that the agents have net wealth of at least 0 in each state of the world. Let $B$ be the agent's initial asset value. Then under agent liability he must receive $\max \left(0, \mathrm{~W}_{\mathrm{D}}^{\mathrm{A}}+\mathrm{B}-\mathrm{D}\right)$. The new Lagrangean is:

$$
\begin{aligned}
\mathrm{L}^{\mathrm{A}}= & \mathrm{p}(\mathrm{x}) \mathrm{U}\left(-\mathrm{W}_{0}\right)+(1-\mathrm{p}(\mathrm{x})) \mathrm{U}\left(\mathrm{W}_{\mathrm{D}}\right) \\
& +\mathrm{k}_{1}\left(\mathrm{p}(\mathrm{x}) \mathrm{V}\left(\mathrm{W}_{\mathrm{0}}+\mathrm{B}\right)+(1-\mathrm{p}(\mathrm{x})) \mathrm{V}\left(\max \left(\mathrm{W}_{\mathrm{D}}+\mathrm{B}-\mathrm{D}, 0\right)\right)\right) \\
& +\mathrm{k}_{2}\left(\mathrm{p}_{\mathrm{x}}(\mathrm{x})\left(\mathrm{V}\left(\mathrm{W}_{0}+\mathrm{B}\right)-\mathrm{V}\left(\max \left(\mathrm{B}+\mathrm{W}_{\mathrm{D}}-\mathrm{D}, 0\right)\right)\right)-\mathrm{C}^{\prime}\right)
\end{aligned}
$$

This changes the first order conditions of $L^{A}$ to

$$
\begin{aligned}
& \mathrm{k}_{1}+\mathrm{k}_{2} \mathrm{P}_{\mathrm{x}} / \mathrm{p}=\mathrm{U}^{\prime}\left(-\mathrm{W}_{0}\right) / \mathrm{V}^{\prime}\left(\mathrm{W}_{0}+\mathrm{B}\right) \\
& \mathrm{k}_{1}-\mathrm{k}_{2} \mathrm{p}_{\mathrm{x}} /(1-\mathrm{p}) \geqslant \mathrm{U}^{\prime}\left(-\mathrm{W}_{\mathrm{D}}\right) / \mathrm{V}^{\prime}\left(\max \left(\mathrm{B}+\mathrm{W}_{\mathrm{D}}-\mathrm{D}, 0\right)\right) \\
& \left(\mathrm{k}_{1}+\mathrm{k}_{2} \mathrm{p}_{\mathrm{x}} / \mathrm{p}-\mathrm{U}^{\prime}\left(-\mathrm{W}_{0}\right) / \mathrm{V}^{\prime}\left(\mathrm{W}_{0}+\mathrm{B}\right)\right) \mathrm{W}_{0}=0 \\
& \begin{array}{l}
\left(k_{1}-k_{2} p_{x} /(1-p)-U^{\prime}\left(-W_{D}\right) / V^{\prime}\left(\operatorname{nax}\left(0,\left(B+W_{D}-D\right)\right)\right)\right) W_{D} \\
=0
\end{array} \\
& \mathrm{p}(\mathrm{x}) \mathrm{V}\left(\mathrm{W}_{0}+\mathrm{B}\right)+(1-\mathrm{p}) \mathrm{V}\left(\operatorname{\operatorname {nax}}\left(\mathrm{B}+\mathrm{W}_{\mathrm{D}}-\mathrm{D}, 0\right)\right)-\mathrm{C}(\mathrm{x})-\overline{\mathrm{V}} \geqslant 0 \\
& \mathrm{p}_{\mathrm{x}}(\mathrm{x})\left(\mathrm{V}\left(\mathrm{W}_{0}+\mathrm{B}\right)-\mathrm{V}\left(\max \left(\mathrm{B}+\mathrm{W}_{\mathrm{D}}-\mathrm{D}, 0\right)\right)-\mathrm{C}^{\prime}(\mathrm{x}) \geqslant 0\right. \\
& \left.\left(\mathrm{p}_{\mathrm{x}}(\mathrm{x}) \mathrm{V}\left(\mathrm{W}_{0}+\mathrm{B}\right)+(1-\mathrm{p}) \mathrm{V}\left(\max \left(\mathrm{B}+\mathrm{W}_{\mathrm{D}}-\mathrm{D}, 0\right)\right)\right)-\mathrm{C}(\mathrm{x})-\overline{\mathrm{V}}\right) \mathrm{k}_{1} \\
& =0 \\
& \left(p_{x}(x)\left(V\left(W_{0}+B\right)-V\left(\max \left(0, B+W_{D}-D\right)\right)\right)-C^{\prime}(x)\right) k_{2}=0 \\
& \left.\mathrm{p}_{\mathrm{x}}(\mathrm{x})\left(\mathrm{U}\left(-\mathrm{W}_{0}\right)-\mathrm{U}\left(-\mathrm{W}_{\mathrm{D}}\right)\right)+\mathrm{k}_{2}\right) \mathrm{p}_{\mathrm{xx}}(\mathrm{x})\left(\mathrm{V}\left(\mathrm{W}_{\mathrm{o}}+\mathrm{B}\right)-\right. \\
& \left.\left.\mathrm{V}\left(\max \left(\mathrm{B}+\mathrm{W}_{\mathrm{D}}-\mathrm{D}, 0\right)\right)\right)-\mathrm{C}^{\prime \prime}\right) \geqslant 0 \\
& \mathrm{P}_{\mathrm{x}}(\mathrm{x})\left(\mathrm{U}\left(-\mathrm{W}_{0}\right)-\mathrm{U}\left(-\mathrm{W}_{\mathrm{D}}\right)\right)+\mathrm{k}_{2}\left(\mathrm { p } _ { \mathrm { xx } } ( \mathrm { x } ) \left(\mathrm{~V}\left(\mathrm{~W}_{\mathrm{o}}+\mathrm{B}\right)-\right.\right. \\
& \left.\mathrm{V}\left(\max \left(\mathrm{B}+\mathrm{W}_{\mathrm{D}}-\mathrm{D}, 0\right)\right)-\mathrm{C}^{\prime \prime}\right) \mathrm{x}=0
\end{aligned}
$$

Let $\left(\mathrm{W}_{0}^{\mathrm{A}}, \mathrm{W}_{\mathrm{D}}^{\mathrm{A}}, \mathrm{x}^{\mathrm{A}}\right)$ maximize $\mathrm{L}^{\mathrm{A}}$.

The first order conditions for $L^{P}$ will be changed accordingly. 
Thus we have

Proposition 2: Suppose the agent's assets B are less than the amount of damage $\mathrm{D}$. Then

(a) if $W_{D}^{A}>0$, then $\left(W_{0}^{A}, W_{D}^{A}, x^{A}\right)$ solves $L^{A}$ if and only if $\left(W_{0}^{A}, W_{D}^{A}-\right.$ $\left.\mathrm{D}, \mathrm{X}^{\mathrm{A}}\right)$ solves $\mathrm{L}^{\mathrm{P}}$.

(b) if $W_{D}^{A}=0$, then

(i) if $W_{D}^{P}=-B$ then $x^{P} \geqslant x^{A}$ and

(ii) if $x^{P}<x^{A}$ then

$$
\mathrm{W}_{0}^{\mathrm{A}}>\mathrm{D}-\mathrm{B}
$$

or

$$
\mathrm{W}_{0}^{\mathrm{P}}<\mathrm{W}_{0}^{\mathrm{A}}>\mathrm{D}-\mathrm{B}<\mathrm{W}_{\mathrm{D}}^{\mathrm{P}}+\mathrm{D}
$$

Proof: (a) if $W_{D}^{A}>0$, we are in the benchmark case and the analysis applied there is correct.

(b) If $W_{D}^{A}=0$, the $W_{D}^{P}=W_{D}^{A}-D$ is 110 feasible as the agent's wage under enterprise liability in the event of an accident. Consequently the solution sets to the problems $L^{A}$ and $L^{P}$ may differ.

Consider (b)(i). We prove that $W_{D}^{P}=-B$ implies that $x^{A} \leqslant x^{P}$ by proving, by contradiction, the contrapositive.

Suppose therefore that $x^{A}>x^{P}$ and contrary to what must be proved that $W_{D}^{P}+B=0=W_{D}^{A}+B-D$. Since

$$
x^{A}>x^{P}
$$

then

$$
\mathrm{V}\left(\mathrm{W}_{0}^{\mathrm{A}}+\mathrm{B}\right)-\mathrm{V}(0)>\mathrm{V}\left(\mathrm{W}_{0}^{\mathrm{P}}+\mathrm{B}\right)-\mathrm{V}(0)
$$

which implies that

$$
\mathrm{W}_{0}^{\mathrm{A}}>\mathrm{W}_{0}^{\mathrm{P}}
$$

Now, note that the fact that $\left(\mathrm{W}_{0}^{\mathrm{P}},-\mathrm{B}, \mathrm{x}^{\mathrm{P}}\right)$ is optimal for enterprise liability implies that $\left(\mathrm{W}_{0}^{\mathrm{P}}, 0, \mathrm{x}^{\mathrm{P}}\right)$ is feasible under agent hability. But

$$
\mathrm{W}_{0}^{\mathrm{P}}<\mathrm{W}_{0}^{\mathrm{A}}
$$


implies that

$$
\mathrm{x}^{\mathrm{A}} \mathrm{U}\left(-\mathrm{W}_{0}^{\mathrm{A}}\right)+\left(1-\mathrm{x}^{\mathrm{A}}\right) \mathrm{U}(0)<\mathrm{x}^{\mathrm{P}} \mathrm{U}\left(-\mathrm{W}_{0}^{\mathrm{P}}\right)+\left(1-\mathrm{x}^{\mathrm{P}}\right) \mathrm{U}(0)
$$

which contradicts the optimality of $\left(\mathrm{W}_{0}^{\mathrm{A}}, 0, \mathrm{x}^{\mathrm{A}}\right)$. Therefore $\mathrm{x}^{\mathrm{A}}>\mathrm{x}^{\mathrm{P}}$ implies that $\mathrm{W}_{\mathrm{D}}^{\mathrm{P}}>-\mathrm{B}$.

Now consider (b)(ii). The optimality of $\left(\mathrm{W}_{0}^{\mathrm{P}}, \mathrm{W}_{\mathrm{D}}^{\mathrm{P}}, \mathrm{x}^{\mathrm{P}}\right)$ under enterprise liability implies that

$$
\min \left(\mathrm{W}_{0}^{\mathrm{P}}, \mathrm{W}_{\mathrm{D}}^{\mathrm{P}}+\mathrm{D}\right)<\max \left(\mathrm{W}_{0}^{\mathrm{A}}, \mathrm{D}-\mathrm{B}\right)
$$

We know that $W_{D}^{P}+D>D-B$ from $b(i)$ as $x^{P}<x^{A}$. So either

$$
\mathrm{W}_{0}^{\mathrm{A}}>\mathrm{D}-\mathrm{B}
$$

or

$$
\mathrm{W}_{0}^{\mathrm{A}}<\mathrm{W}_{0}^{\mathrm{P}}<\mathrm{D}-\mathrm{B}
$$

or

$$
\mathrm{W}_{0}^{\mathrm{P}}<\mathrm{W}_{0}^{\mathrm{A}}<\mathrm{D}-\mathrm{B}
$$

Consider (40). We know that

$$
\begin{array}{r}
\mathrm{p}\left(\mathrm{x}^{\mathrm{P}}\right) \mathrm{U}\left(-\mathrm{W}_{0}^{\mathrm{P}}\right)+\left(1-\mathrm{p}\left(\mathrm{x}^{\mathrm{P}}\right)\right) \mathrm{U}\left(-\mathrm{W}_{\mathrm{D}}^{\mathrm{P}}-\mathrm{D}\right)<\mathrm{p}\left(\mathrm{x}^{\mathrm{P}}\right) \mathrm{U}\left(-\mathrm{W}_{0}^{\mathrm{P}}\right)+ \\
\left(1-\mathrm{p}\left(\mathrm{x}^{\mathrm{P}}\right)\right) \mathrm{U}(\mathrm{B}-\mathrm{D}) \\
<\mathrm{p}\left(\mathrm{x}^{\mathrm{A}}\right) \mathrm{U}\left(-\mathrm{W}_{0}^{\mathrm{P}}\right)+\left(1-\mathrm{p}\left(\mathrm{x}^{\mathrm{A}}\right)\right) \mathrm{U}(\mathrm{B}-\mathrm{D}) \\
<\mathrm{p}\left(\mathrm{x}^{\mathrm{A}}\right) \mathrm{U}\left(-\mathrm{W}_{0}^{\mathrm{A}}\right)+\left(1-\mathrm{p}\left(\mathrm{x}^{\mathrm{A}}\right)\right) \mathrm{U}(\mathrm{B}-\mathrm{D})
\end{array}
$$

contradicting the optimality of $\left(\mathrm{W}_{0}^{\mathrm{P}}, \mathrm{W}_{\mathrm{D}}^{\mathrm{P}}, \mathrm{x}^{\mathrm{P}}\right)$. Q.E.D.

c. The Safe Work Environment Case

Here the probability of an accident $\mathrm{p}(\mathrm{x}, \mathrm{y})$ depends on principalcare $y$ as well as agent-care $x$. The new Lagrangean is

$$
\begin{aligned}
L^{A} & =p(x, y) U\left(-W_{0}-y\right)+(1-p(x, y)) U\left(-W_{D}-y\right) \\
& \left.+k_{1}\left(p(x, y) V\left(W_{0}\right)+(1-p) V\left(W_{D}-D\right)-C\right)\right) \\
& +k_{2}\left(p_{x}(x)\left(V\left(W_{0}\right)-V\left(W_{D}-D\right)\right)-C^{\prime}\right)
\end{aligned}
$$


Thus, under agent hability the principal maximizes $L^{A}$ over $\left(\mathrm{W}_{0}, \mathrm{~W}_{\mathrm{D}}-\mathrm{D}, \mathrm{x}, \mathrm{y}\right)$. This yields an additional first-order condition:

$$
\begin{aligned}
& \mathrm{p}_{y}(\mathrm{x}, \mathrm{y})\left(\mathrm{U}\left(-\mathrm{W}_{0}-\mathrm{y}\right)-\mathrm{U}\left(-\mathrm{W}_{\mathrm{D}}-\mathrm{y}\right)\right) \\
& +\mathrm{k}_{1} \mathrm{p}_{\mathrm{y}}(\mathrm{x}, \mathrm{y})\left(\mathrm{V}\left(\mathrm{W}_{\mathrm{o}}\right)-\mathrm{V}\left(\mathrm{W}_{\mathrm{D}}-\mathrm{D}\right)\right) \\
& +\mathrm{k}_{2} \mathrm{p}_{\mathrm{xy}}(\mathrm{x}, \mathrm{y})\left(\mathrm{V}\left(\mathrm{W}_{0}\right)-\mathrm{V}\left(\mathrm{W}_{\mathrm{o}}-\mathrm{D}\right)\right) \\
& -\left(\mathrm{p}(\mathrm{x}, \mathrm{y}) \mathrm{U}^{\prime}\left(-\mathrm{W}_{0}-\mathrm{y}\right)\right. \\
& \left.+(1-\mathrm{p}(\mathrm{x}, \mathrm{y})) \mathrm{U}^{\prime}\left(-\mathrm{W}_{\mathrm{D}}-\mathrm{y}\right)\right)=0
\end{aligned}
$$

$\mathrm{L}^{\mathrm{P}}$ would be appropriately refornnulated.

Proposition 3: $\left(\mathrm{W}_{0}, \mathrm{~W}_{\mathrm{D}}, \mathrm{x}, \mathrm{y}\right)$ maximizes $\mathrm{L}^{\mathrm{A}}$ if and only if $\left(\mathrm{W}_{0}, \mathrm{~W}_{\mathrm{D}}-\mathrm{D}, \mathrm{x}, \mathrm{y}\right)$ maximizes $\mathrm{L}^{\mathrm{P}}$.

The proof follows the model of proposition 1 .

\section{d. The Screening Case}

There are two types of agents distimguished by their costs of care. Let $\mathrm{C}_{1}{ }^{\prime}<\mathrm{C}_{2}{ }^{\prime}$. By expending $\mathrm{s}$ the principal can expect an agent of type 1 with probability $\mathrm{g}(\mathrm{s})$. Under agent liability the principal maximizes over $\left(\mathrm{W}_{0}, \mathrm{~W}_{\mathrm{D}}, \mathrm{s}, \mathrm{x}_{1}, \mathrm{x}_{2}\right)$ where $\mathrm{x}_{1}$ is the care choice of type 1 agents and $\mathrm{x}_{2}$ of type 2 agents:

$$
\begin{aligned}
\mathrm{L}^{\mathrm{A}} & =\mathrm{g}(\mathrm{s})\left(\mathrm{p}\left(\mathrm{x}_{1}\right) \mathrm{U}\left(-\mathrm{W}_{0}-\mathrm{s}\right)+\left(1-\mathrm{p}\left(\mathrm{x}_{1}\right)\right) \mathrm{U}\left(-\mathrm{W}_{0}-\mathrm{s}\right)\right) \\
& +(1-\mathrm{g}(\mathrm{s}))\left(\mathrm{p}\left(\mathrm{x}_{2}\right) \mathrm{U}\left(-\mathrm{W}_{0}-\mathrm{s}\right)\right. \\
& \left.+\left(1-\mathrm{p}\left(\mathrm{x}_{2}\right)\right) \mathrm{U}\left(-\mathrm{W}_{\mathrm{D}}-\mathrm{s}\right)\right) \\
& +\mathrm{k}_{1}^{1}\left(\mathrm{p}\left(\mathrm{x}_{1}\right) \mathrm{V}\left(\mathrm{W}_{0}\right)+\left(1-\mathrm{p}\left(\mathrm{x}_{1}\right)\right) \mathrm{V}\left(\mathrm{W}_{\mathrm{D}}-\mathrm{D}\right)-\mathrm{C}_{1}\left(\mathrm{x}_{1}\right)-\overline{\mathrm{V}}_{1}\right) \\
& +\mathrm{k}_{2}^{1}\left(\mathrm{p}_{\mathrm{x}}\left(\mathrm{x}_{1}\right)\left(\mathrm{V}\left(\mathrm{W}_{0}\right)-\mathrm{V}\left(\mathrm{W}_{\mathrm{D}}-\mathrm{D}\right)\right)-\mathrm{C}_{1}{ }^{\prime}\left(\mathrm{x}_{1}\right)\right) \\
& +\mathrm{k}_{1}^{2}\left(\mathrm{p}_{1}\left(\mathrm{x}_{2}\right) \mathrm{V}\left(\mathrm{W}_{0}\right)+\left(1-\mathrm{p}\left(\mathrm{x}_{2}\right)\right) \mathrm{V}\left(\mathrm{W}_{\mathrm{D}}-\mathrm{D}\right)-\mathrm{C}_{2}\left(\mathrm{x}_{2}\right)-\overline{\mathrm{V}}_{2}\right) \\
& \left.+\mathrm{k}_{2}^{2}\left(\mathrm{p}_{\mathrm{x}}\left(\mathrm{x}_{2}\right)(\mathrm{V})\left(\mathrm{W}_{0}\right)-\mathrm{V}\left(\mathrm{W}_{\mathrm{D}}-\mathrm{D}\right)\right)-\mathrm{C}_{2}{ }^{\prime}\left(\mathrm{x}_{2}\right)\right)
\end{aligned}
$$

The first-order conditions are

$$
\begin{aligned}
& -\left(\mathrm{p}\left(\mathrm{x}_{1}\right) \mathrm{g}(\mathrm{s})+(1-\mathrm{g}(\mathrm{s})) \mathrm{p}\left(\mathrm{x}_{2}\right)\right) \mathrm{U}^{\prime}\left(-\mathrm{W}_{0}-\mathrm{s}\right) \\
& \quad+\left(\mathrm{k}_{1}^{1} \mathrm{p}\left(\mathrm{x}_{1}\right)+\mathrm{k}_{1}^{2} \mathrm{p}\left(\mathrm{x}_{2}\right)\right) \mathrm{V}^{\prime}\left(\mathrm{W}_{0}\right)+\left(\mathrm{k}_{2}^{1} \mathrm{p}_{\mathrm{x}}\left(\mathrm{x}_{1}\right)\right. \\
& \left.\quad+\mathrm{k}_{2}^{2} \mathrm{p}_{\mathrm{x}}\left(\mathrm{x}_{2}\right)\right) \mathrm{V}^{\prime}\left(\mathrm{W}_{0}\right)=0 \\
& -\left(\mathrm{g}(\mathrm{s})\left(1-\mathrm{p}\left(\mathrm{x}_{1}\right)\right)+(1-\mathrm{g}(\mathrm{s}))\left(1-\mathrm{p}\left(\mathrm{x}_{2}\right)\right)\right) \mathrm{U}^{\prime}\left(-\mathrm{W}_{\mathrm{D}}-\mathrm{s}\right) \\
& \quad+\left(\mathrm{k}_{1}^{1}\left(1-\mathrm{p}\left(\mathrm{x}_{1}\right)\right)+\mathrm{k}_{1}^{2}\left(1-\mathrm{p}\left(\mathrm{x}_{2}\right)\right)\right) \mathrm{V}^{\prime}\left(\mathrm{W}_{\mathrm{D}}-\mathrm{D}\right) \\
& \quad-\left(\mathrm{k}_{2}^{1} \mathrm{p}_{\mathrm{x}}\left(\mathrm{x}_{1}\right)+\mathrm{k}_{1}^{2} \mathrm{p}_{\mathrm{x}}\left(\mathrm{x}_{2}\right)\right) \mathrm{V}\left(\mathrm{W}_{\mathrm{D}}-\mathrm{D}\right)=0 \\
& \mathrm{~g}^{\prime}(\mathrm{s})\left(\mathrm{E}\left(\mathrm{U} \mid \mathrm{x}_{1}\right)-\mathrm{E}\left(\mathrm{U}^{\mathrm{N}} \mid \mathrm{x}_{2}\right)\right)-\mathrm{g}(\mathrm{s}) \mathrm{E}\left(\mathrm{U}^{\prime} \mid \mathrm{x}_{1}\right) \\
& \quad-(1-\mathrm{g}(\mathrm{s})) \mathrm{E}\left(\mathrm{U}^{\prime} \mid \mathrm{x}_{2}\right)=0
\end{aligned}
$$




$$
\begin{array}{ll}
\mathrm{p}\left(\mathrm{x}_{\mathrm{i}}\right) \mathrm{V}\left(\mathrm{W}_{0}\right)+\left(1-\mathrm{p}\left(\mathrm{x}_{\mathrm{i}}\right)\right) \mathrm{V}\left(\mathrm{W}_{\mathrm{D}}-\mathrm{D}\right)-\mathrm{C}_{\mathrm{i}}\left(\mathrm{x}_{\mathrm{i}}\right)-\overline{\mathrm{V}}_{\mathrm{i}}=0 \quad \mathrm{i}=1,2 \\
\mathrm{p}_{\mathrm{x}}\left(\mathrm{x}_{\mathrm{i}}\right)\left(\mathrm{V}\left(\mathrm{W}_{0}\right)-\mathrm{V}\left(\mathrm{W}_{\mathrm{D}}-\mathrm{D}\right)\right)-\mathrm{C}_{\mathrm{i}}^{\prime}\left(\mathrm{x}_{\mathrm{i}}\right)=0 \quad \mathrm{i}=1,2
\end{array}
$$

Proposition 4: $\left(\mathrm{W}_{0}, \mathrm{~W}_{\mathrm{D}}, \mathrm{s}, \mathrm{x}_{1}, \mathrm{x}_{2}\right)$ maximizes $\mathrm{L}^{\mathrm{P}}$ if and only if $\left(\mathrm{W}_{0}\right.$, $\mathrm{W}_{\mathrm{D}}+\mathrm{D}, \mathrm{s}, \mathrm{x}_{1}, \mathrm{x}_{2}$ ) maximizes $\mathrm{L}^{\mathrm{A}}$.

The proof follows that of proposition 1 .

\section{e. The Multiple-Agent Problem}

The problem under agent liability is equivalent to the case in which courts, under agent liability can attribute liability to an agent with the probability $r, 0<r<1$, while liability is always attributed to the enterprise under enterprise liability, and the enterprise always holds some agent responsible.

Designate the principal's maximization problem under agent hability and with attribution rate $r$ with the superscript Ar. The Lagrangian would be:

$$
\begin{aligned}
L^{A r}= & \left(p^{r}(x) U\left(-W_{0}\right)+\left(1-p^{r}(x)\right) U\left(-W_{D}\right)\right)+k_{1}\left(p^{r}(x) V\left(W_{0}\right)+\right. \\
& \left.\left(1-p^{r}(x)\right) V\left(W_{D}\right)-C(x)-\bar{V}\right)+k_{2}\left(p _ { x } ^ { r } ( x ) \left(V\left(W_{0}\right)-\right.\right. \\
& \left.\left.V\left(W_{D}\right)\right)-C^{\prime}\right)
\end{aligned}
$$

It is easy to see that a solution for $\mathrm{L}^{\mathrm{Ar}}$ is identical to a solution to the benchmark problem with the probability of an accident defined by

$$
p^{r}(x)=(p(x)+(1-r)(1-p(x))>p(x) \text { all } x
$$

and

$$
\mathrm{p}_{\mathrm{x}}^{\mathrm{r}}(\mathrm{x})=\mathrm{rp}_{\mathrm{x}}(\mathrm{x})<\mathrm{p}_{\mathrm{x}}(\mathrm{x}) \text { all } \mathrm{r} \text { and } \mathrm{x}
$$

Let $x^{r}(W)$ denote the agent's optimal response to the compensation scheme $W=\left(W_{0}, W_{D}\right)$ when agent liability applies and agents are found lible with probability $r$. Let $\left(\mathrm{W}^{\mathrm{r}}, \mathrm{x}^{\mathrm{r}}\left(\mathrm{W}^{\mathrm{r}}\right)\right)$ solve $\mathrm{L}^{\mathrm{Ar}}$. We may now state: Proposition 5: Suppose under agent liability the courts can attribute liability with probability $r, r$ in $(0,1)$ while under enterprise liability courts attribute liability with probability 1 .

Then

(a) $\mathrm{x}^{\mathrm{r}}\left(\mathrm{W}^{\mathrm{r}}\right)<\mathrm{x}^{1}\left(\mathrm{~W}^{1}\right)$; and

(b) the principal prefers agent liability if and only if

$$
\mathrm{p}^{\mathrm{r}}\left(\mathrm{x}^{\mathrm{r}}\left(\mathrm{W}^{\mathrm{r}}\right)\right) / \mathrm{p}^{1}\left(\mathrm{x}\left(\mathrm{W}^{1}\right)\right)>\left(\mathrm{U}\left(-\mathrm{W}_{0}^{1}\right)-\mathrm{U}\left(-\mathrm{W}_{\mathrm{D}}\right) /\left(\mathrm{U}\left(-\mathrm{W}_{0}^{\mathrm{r}}\right)-\right.\right.
$$

$$
\left.\mathrm{U}\left(-\mathrm{W}_{\mathrm{D}}\right)\right)
$$

Proof: Under agent hability the principal solves the constramed max- 
imization problem $L^{A r}$. Under enterprise liability the principal solves the constramed maximization problem $L^{\mathrm{P1}}$ which by proposition 1 is equivalent to the solution of $\mathrm{L}^{\mathrm{A} 1}$. We need only compare $\left(\mathrm{W}^{\mathrm{r}}, \mathrm{x}^{\mathrm{r}}\left(\mathrm{W}^{\mathrm{r}}\right)\right)$ to $\left(\mathrm{W}^{1}, \mathrm{x}^{1}\left(\mathrm{~W}^{1}\right)\right)$.

To prove part (a) consider the first-order conditions for $L^{r}$ as a function of $\mathrm{r}$ :

$$
\begin{aligned}
& U^{\prime}\left(-W_{0}^{r}\right) / V^{\prime}\left(W_{0}^{r}\right)=k_{1}+k_{2} r p_{x}^{1} /\left(p^{1}+(1-r)\left(1-p^{1}\right)\right) \\
& U^{\prime}\left(-W_{D}^{r}\right) / V^{\prime}\left(W_{D}^{r}\right)=k_{1}-k_{2} p_{x}^{1} /\left(1-p^{1}\right)
\end{aligned}
$$

Differentiating implicitly for $\mathrm{W}_{\mathrm{i}}$ and $\mathrm{r}$ we discover the $\partial \mathrm{W}_{0}^{\mathrm{r}} / \partial \mathrm{r}$ is positive and $\partial \mathrm{W}_{\mathrm{D}}^{\mathrm{r}} / \partial \mathrm{r}$ is zero. Thus, as $\mathrm{r}$ decreases, $\mathrm{V}\left(\mathrm{W}_{0}^{\mathrm{r}}\right)-\mathrm{V}\left(\mathrm{W}_{\mathrm{D}}^{\mathrm{r}}\right)$ decreases and $x^{x}<x^{1}$. This unay be seen formally by differentiating the agent's optimization problem implicitly for $x$ and $x$.

To prove part (b) simply compare the principal's expected utility under agent and enterprise liability. The condition of part (b) follows immediately from rearranging terms. Q.E.D.

The risk-aversion of the agent assures that under agent liability, $\mathrm{W}_{0}^{\mathrm{r}}<\mathrm{W}_{0}^{1}<\mathrm{W}_{\mathrm{D}}^{\mathrm{r}}=\mathrm{W}_{\mathrm{D}}^{1}$. Therefore, the right-hand side of the condition $\mathrm{m}(57)$ is less than 1 and a sufficient condition for the principal to prefer agent to enterprise hability is that $p^{x}\left(x^{r}\right)$ exceed or equal $p^{1}\left(x^{1}\right)$. This is true for small $r$. While it seems plausible for all $r, I$ have been unable to show it to be true. Intuitively, as $r$ decreases, the expected damages should decrease as the attribution rate decreases. But the care level also decreases so that the total number of accidents increases. It is therefore conceivable that expected daunage payments rise as the attribution rate declines. The principal would then only prefer agent hability if the wage in the event of no accident has declined sufficiently.

\section{f. Extensions of the Model}

We may also consider $L^{A r}$ as a (continuous) function of $D$. This allows us to conclude that a $D^{r}>D$ exists that holds the principal to the utility level attained under perfect attribution. The analysis could proceed equally easily if we assume the dannage annount $D$ is distributed with density $f(D ; x), F_{x} \leqslant 0$. The compensation scheme will then be a function $W(D)$. As $L^{A}(W(D), x)=L^{P}(W(D)-D, x)$ the identical arguments apply.

The analysis has considered only accidents that are unrelated to productivity but it may easily be extended to the more coinplicated case. Designate the value of the output produced by the agent by $z$. The value of the output depends on the agent's choice of $x$ and soine random event. The value of $z$ is jointly distributed with the amount of external damage $D$ according to density $f(z, D ; x)$. The problem for the primcipal then is to choose a wage schedule $W(z, D)$ that maximizes $\mathrm{EU}(\mathrm{z}-\mathrm{W}(\mathrm{z}, \mathrm{D}))$ subject to (i) $\mathrm{EV}(\mathrm{W}(\mathrm{z}, \mathrm{D})-\mathrm{D})-\mathrm{C}(\mathrm{x}) \geqslant \overline{\mathrm{V}}$ and (ii) the agent chooses $x$ optimally. 
Under enterprise liability the principal chooses $\mathrm{W}^{\mathrm{P}}(\mathrm{z}, \mathrm{D})$ to maximize $E U\left(z-W^{P}(z, D)-D\right)$ subject to (i) $E V\left(s^{P}(z, D)\right)-C(s) \geqslant \bar{V}$ and (ii) the agent chooses $x$ optimally.

The arguments used in the simpler problem carry over to the inore complex case.

\section{B. Criticism of a Recent Note on Principal-Agent Liability}

After the penultimate draft of this Article was submitted to this Review for consideration, Note, An Efficiency Analysis of Vicarious Liability Under the Law of Agency, 91 YALE L.J. 168 (1981) was called to my attention.

That Note and this Article use a similar economic inodel (but, unfortunately, significantly different notation) for somewliat different purposes. Only the case of limited liability ("judgment proof agent" in the Note's terminology) is analyzed explicitly by botll pieces and on that issue the two disagree.

The Note implicitly provides an analysis of the "benchmark case" of the Article. Here both pieces agree. The Note analyzes two cases not considered by this Article: It considers (1) situations in which neither principal nor agent responds to the tort imcentive, so the assignment of hability does not matter; and (2) situations in which the principal observes perfectly the agent's choice of care, and again the assignment of liability does not matter.

This Article examines several cases not considered by the Note. All of these are variations of the basic benchmark case, called by the Note agent-momitored activities. I consider, in addition to the benchmark and limited liability cases, situations in which (1) the principal can at the time of hiring screen for careful agents; (2) the principal's choice of work environment affects the probability of accidents; (3) external factors restrict the range of employinent contracts an einployer may offer; (4) differences exist between the liability regimes distmct from the nominal assignment of liability (e.g. differential enforcement costs); (5) accidents are caused by many agents; (6) differences exist betwcen judicial enterprises and accuracy of observing agent care levels.

The principal normative use of the Note is to suggest the appropriate elaboration of the control test in agency law. This Article's principal focus is on the levels of care produced by enterprise and agent liability, and on the implications resulting from the assignment of liability to private enterprises and to public enterprises and officials. Finally, the heuristic explanation of the models differ dramatically.

This Section of the Appendix explains the discrepancy between the Note's analysis of the limited liability case and my analysis. The Note concludes that " $\mathrm{m}$ agent-1nomitored activities, the imposition of vicarious liability generally reduces the level of precautionary beliavior" (pp. 
186-87). The Note purports to prove this statement in its Appendix VI but unfortunately the proof is erroneous, as is, at times, the conclusion. It is possible that enterprise hability (or vicarious hability) leads to less care than agent liability but it is not likely and certainly not always the case.

To begin with I provide a lexicon for translating the Note's notation into mine (the left hand symbol is the Note's; the right hand symbol is mine):

$$
\begin{aligned}
& \mathrm{y}_{\mathrm{n}}=\mathrm{W}_{\mathrm{o}} \\
& \mathrm{y}_{\mathrm{a}}=\mathrm{W}_{\mathrm{D}} \\
& \mathrm{y}_{0}=\mathrm{B} \\
& \mathrm{e}=\mathrm{x}
\end{aligned}
$$

superscript $\mathrm{v}=$ superscript $P$

superscript $\mathbf{j}=$ superscript $A$

The Note claims the in the case of limited liability $x^{A}>x^{P}\left(e^{j}>\right.$ $\left.e^{v}\right)$ when $W_{D}^{A}=0\left(y_{a}^{j}=0\right)$. (Appendix VI(i)). In addition the Note claims that $\mathrm{W}_{0}^{\mathrm{A}}>\mathrm{W}_{0}^{\mathrm{P}}$. This combination of conditions is impossible because it violates the axion that the principal maximize her liability. If the agent was willing to work under enterprise hability for the proposed contract he should be willing to work under agent liability when wages are set at $\mathrm{W}_{\mathrm{D}}=0$ and $\mathrm{W}_{0}=\mathrm{W}_{0}^{\mathrm{P}}$. But this regime is less expensive to the principal so the imitial contract $\left(W_{0}^{D}, 0\right)$ was not optimal.

The Note's proffered proof in Appendix VI contams two errors. First, it relies on the argunent in Appendix III which is in error. Appendix III apparently divides the choice of wage contract from the choice of precautionary level. But the principal chooses the wage contract anticipating the care response of the agent. It is natural to model the problein by having the principal maximize her utility subject to the agent's reservation utility and optimal response to the wage differential. But in Appendices II and III the Note inodels the problem as an agent maximization problem. This forn ignores the leader-follower nature of the economic setting and vitiates the Note's analysis. Second, in Appendix VI the Note assumes that no party obtains greater expected utility in the presence of vicarious hability. This assumption is unwarranted. The agent may benefit from the regime of enterprise hability. ${ }^{40}$

One other comment on the Note is merited. In Appendix VI(ii) the Note states a theorem that is the partial converse of iny proposition 2(b)(ii). Unfortunately, the proof relies on Appendix III which has, as noted above, an erroneous fornulation of the inaximization problem. I have not been able to prove the stated theoren nor to provide a counterexainple.

40. See supra pp.1365-66. 